\title{
O canto das rochas
}

lissa sakajiri

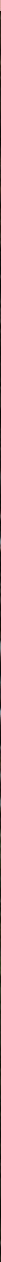



o canto das rochas

lissa sakajiri 


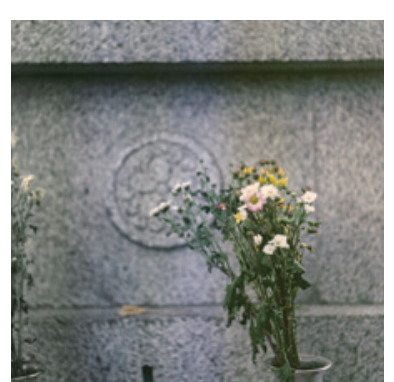


閑かさゃ 岩にしみる

蝉の声

松尾 芭蕉
Silêncio

o canto das cigarras infiltra as rochas

Matsuo Bashō 


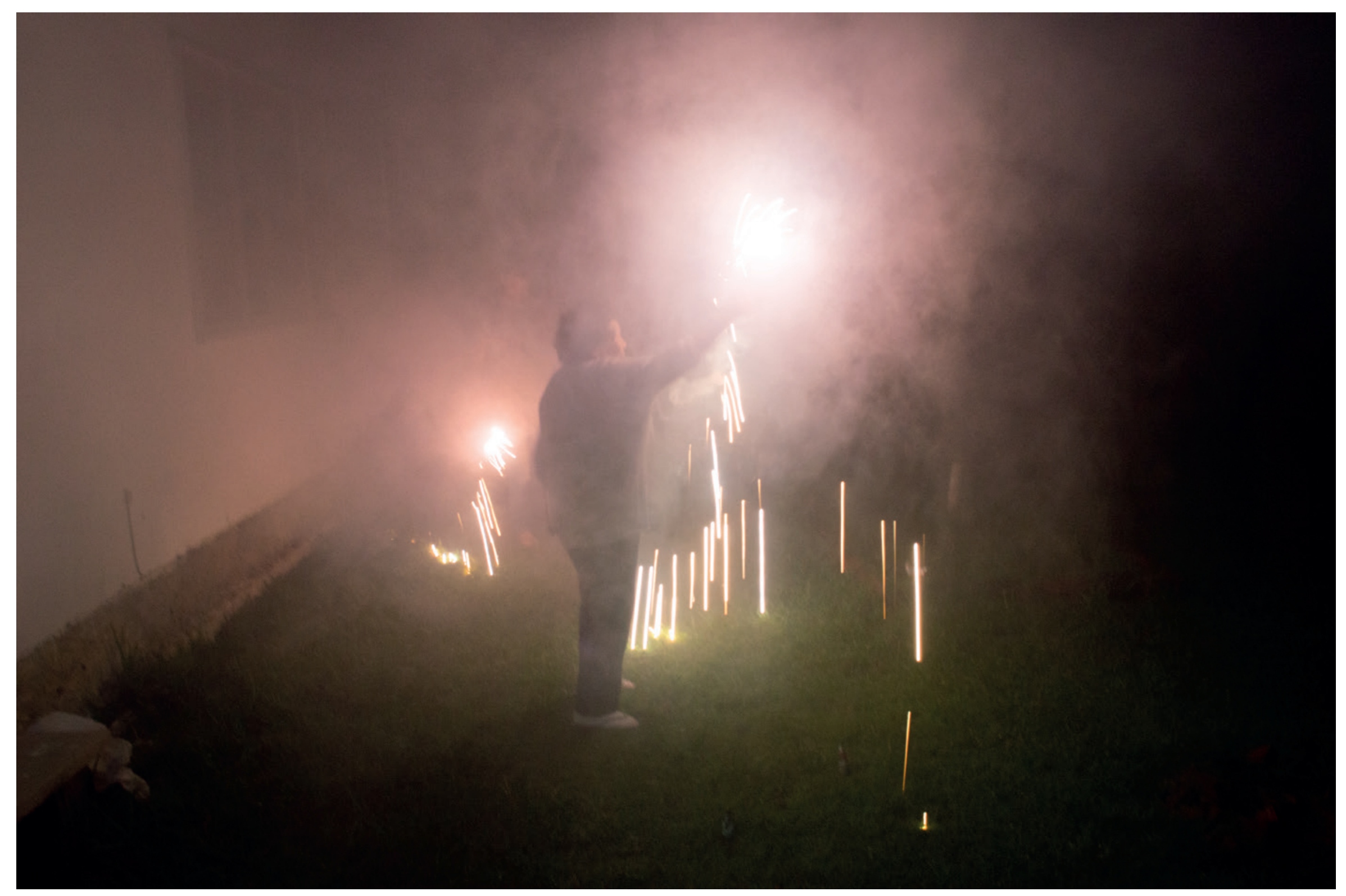




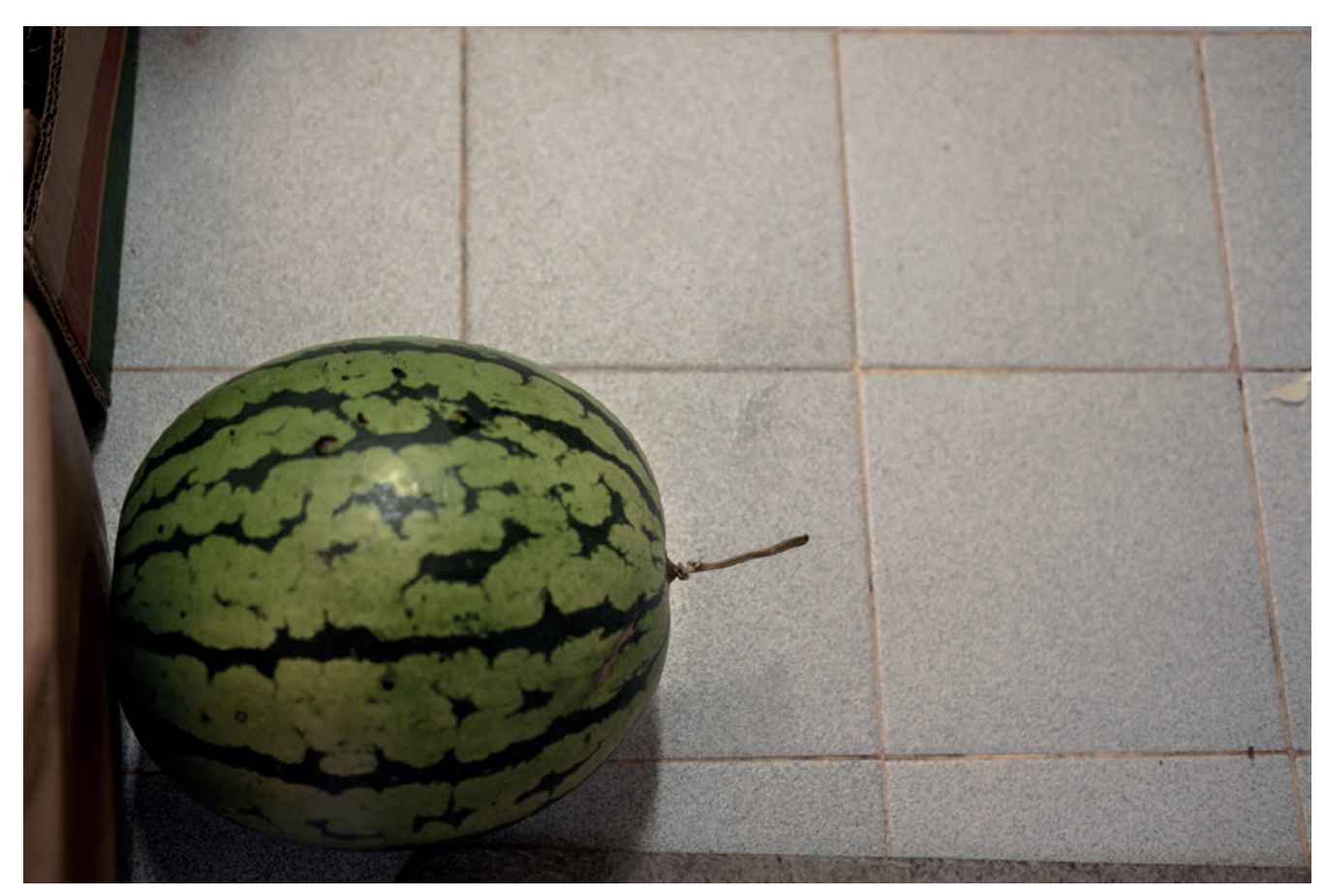




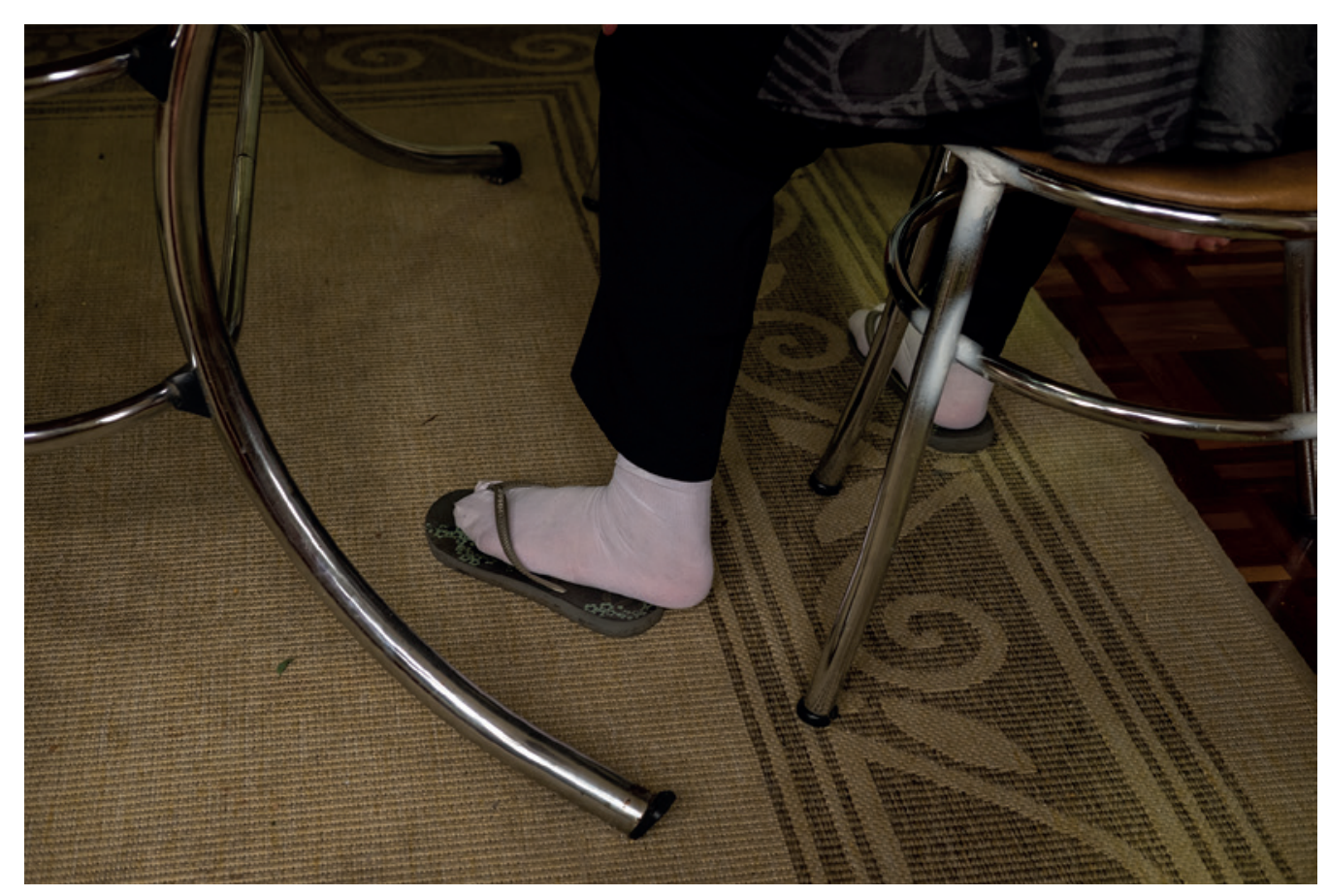




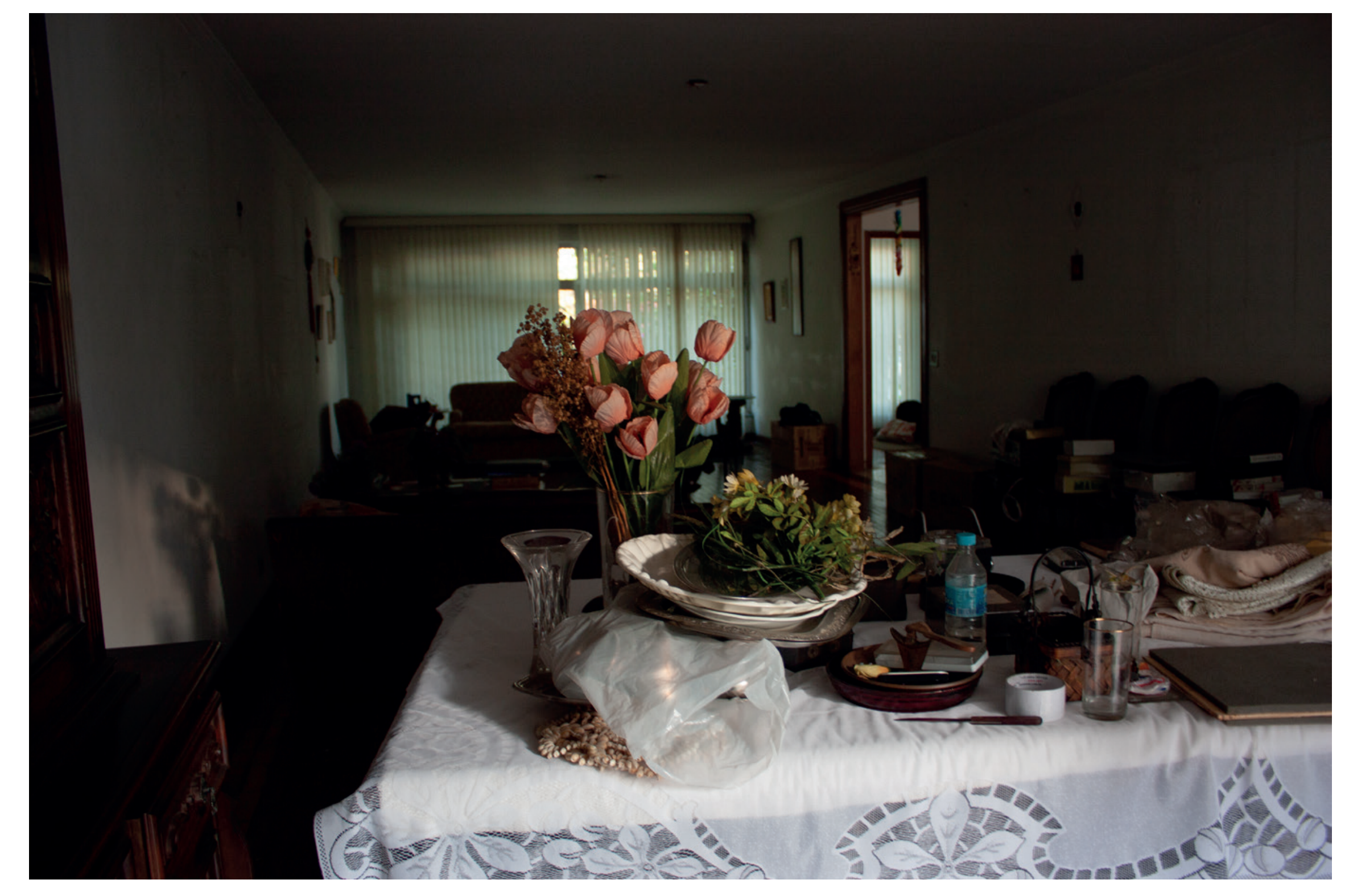




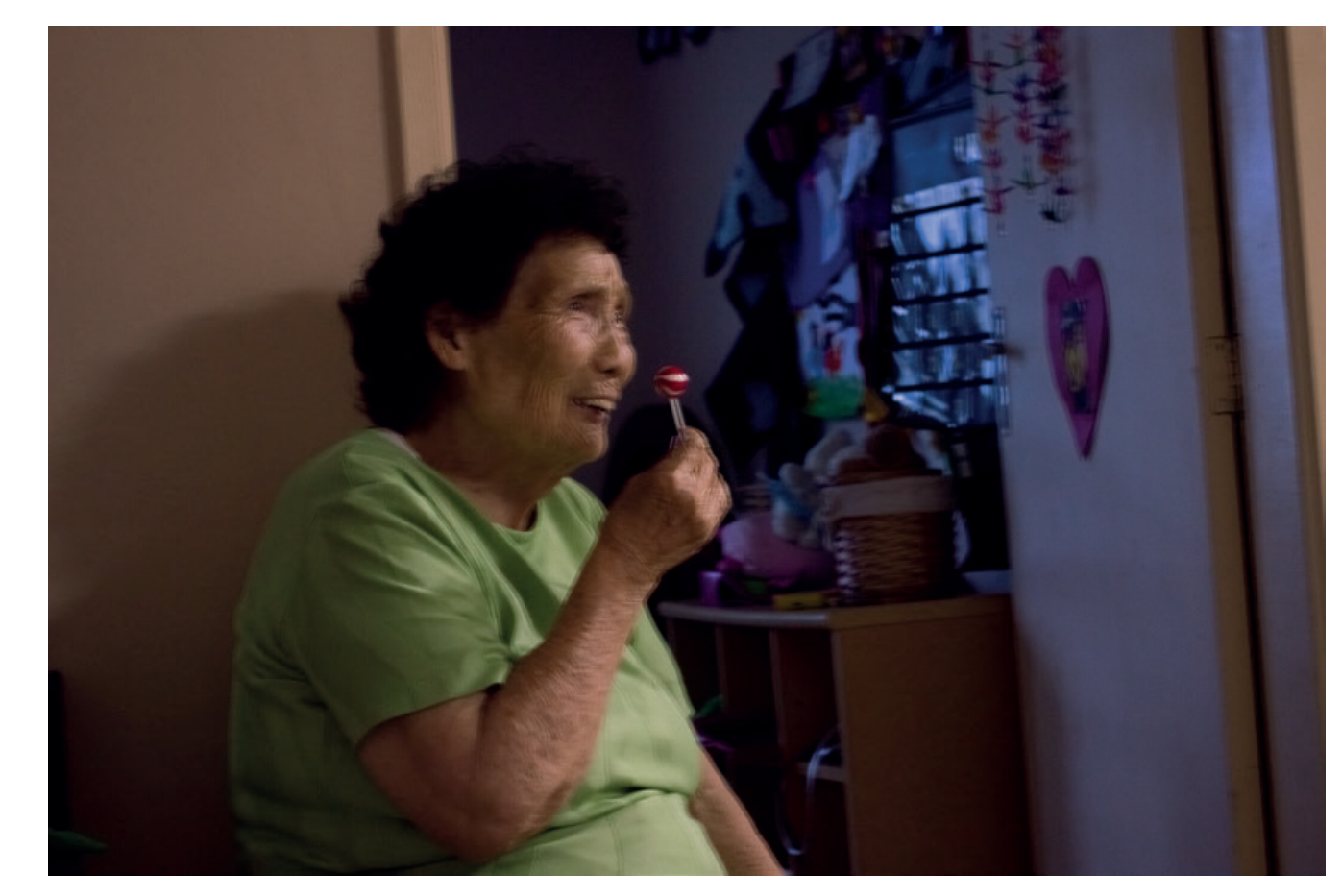




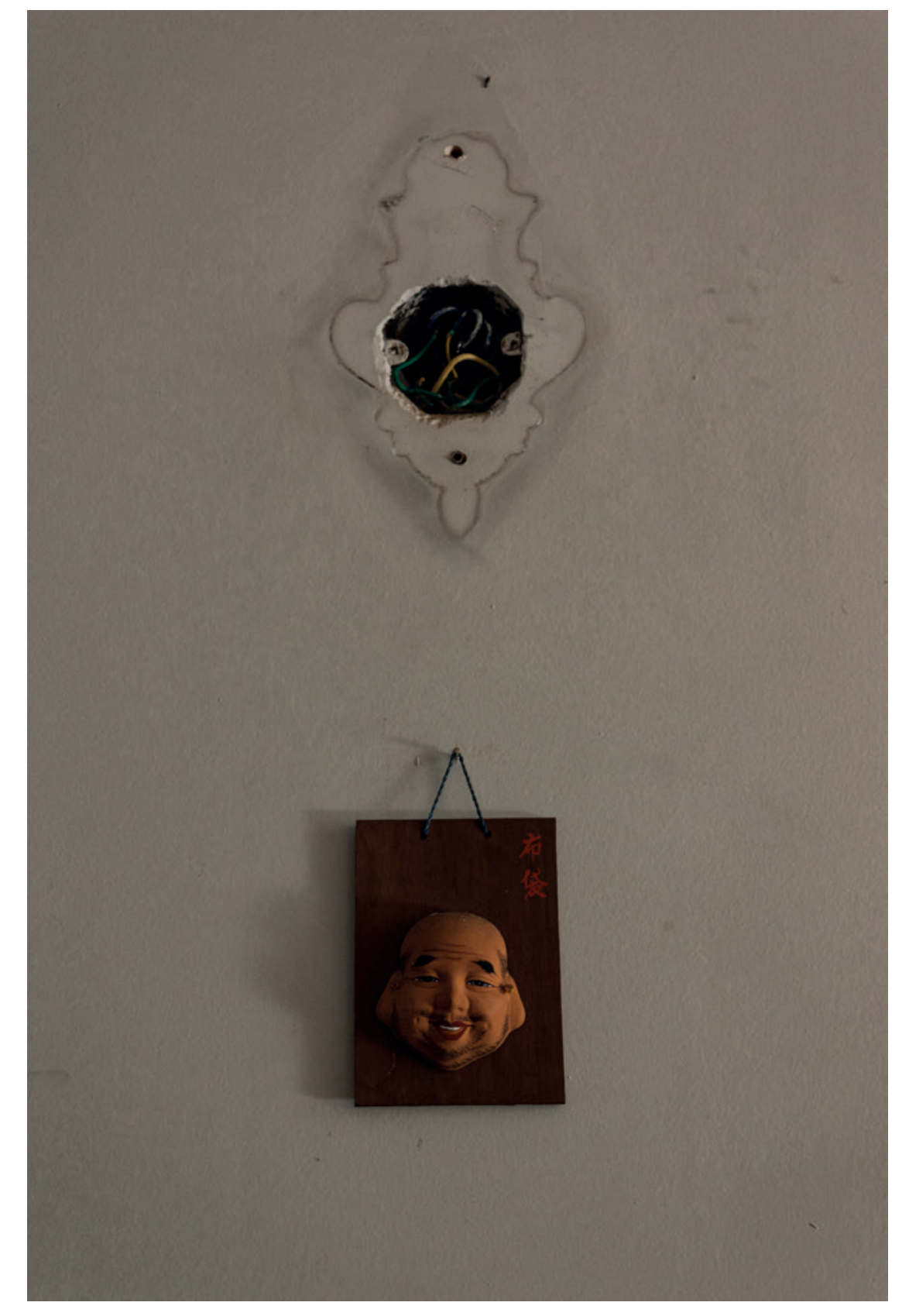




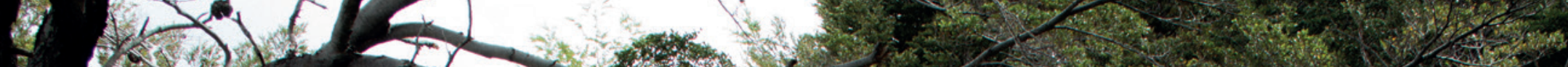
(n)

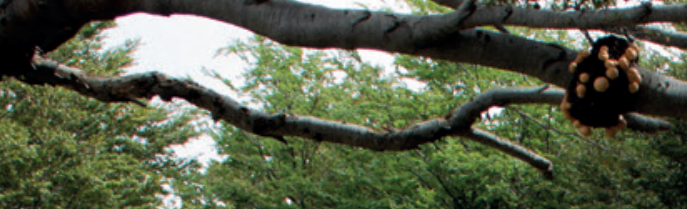

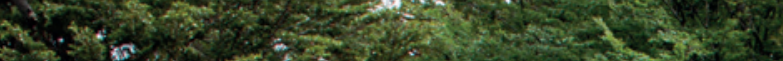

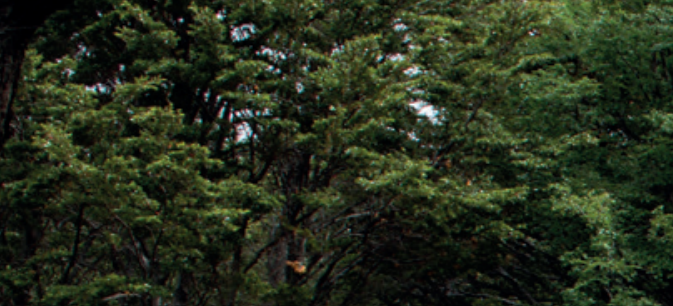
$\sum_{x \rightarrow 1}$ $x=y^{2}+23$
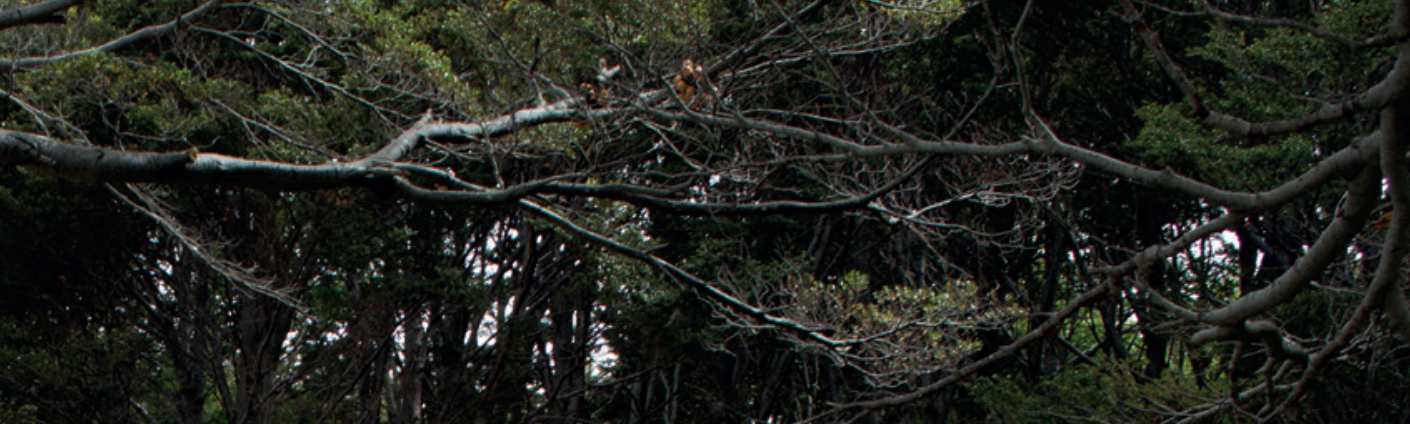

$\infty$

inget:

art

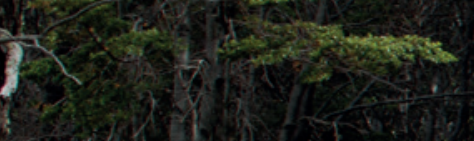

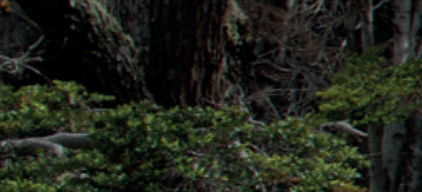

ist

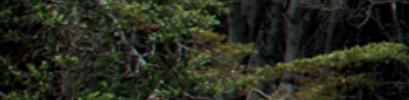

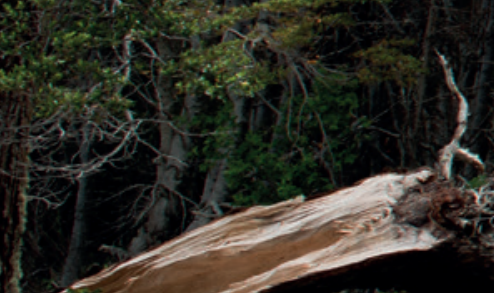

$2, \pi$ ? $\operatorname{sen}^{(4)}$ 21010 6rosing

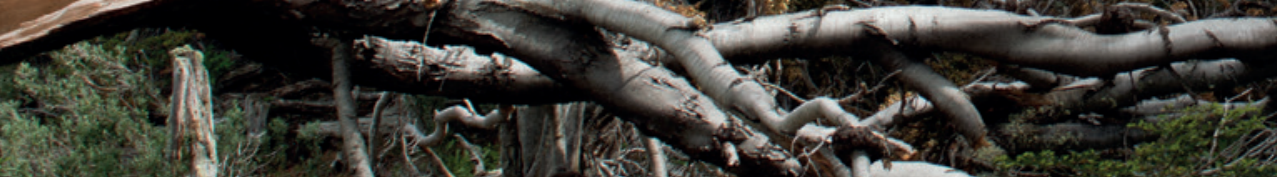

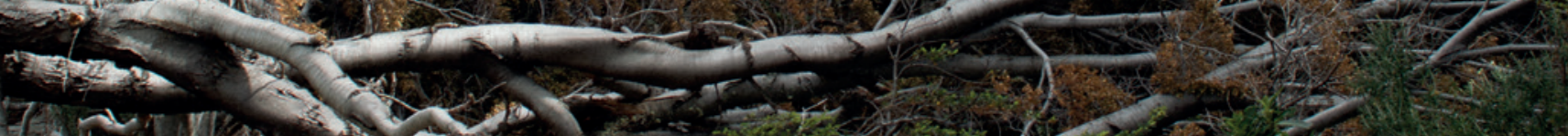

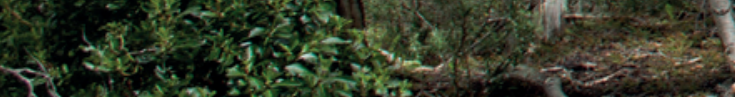
t. 


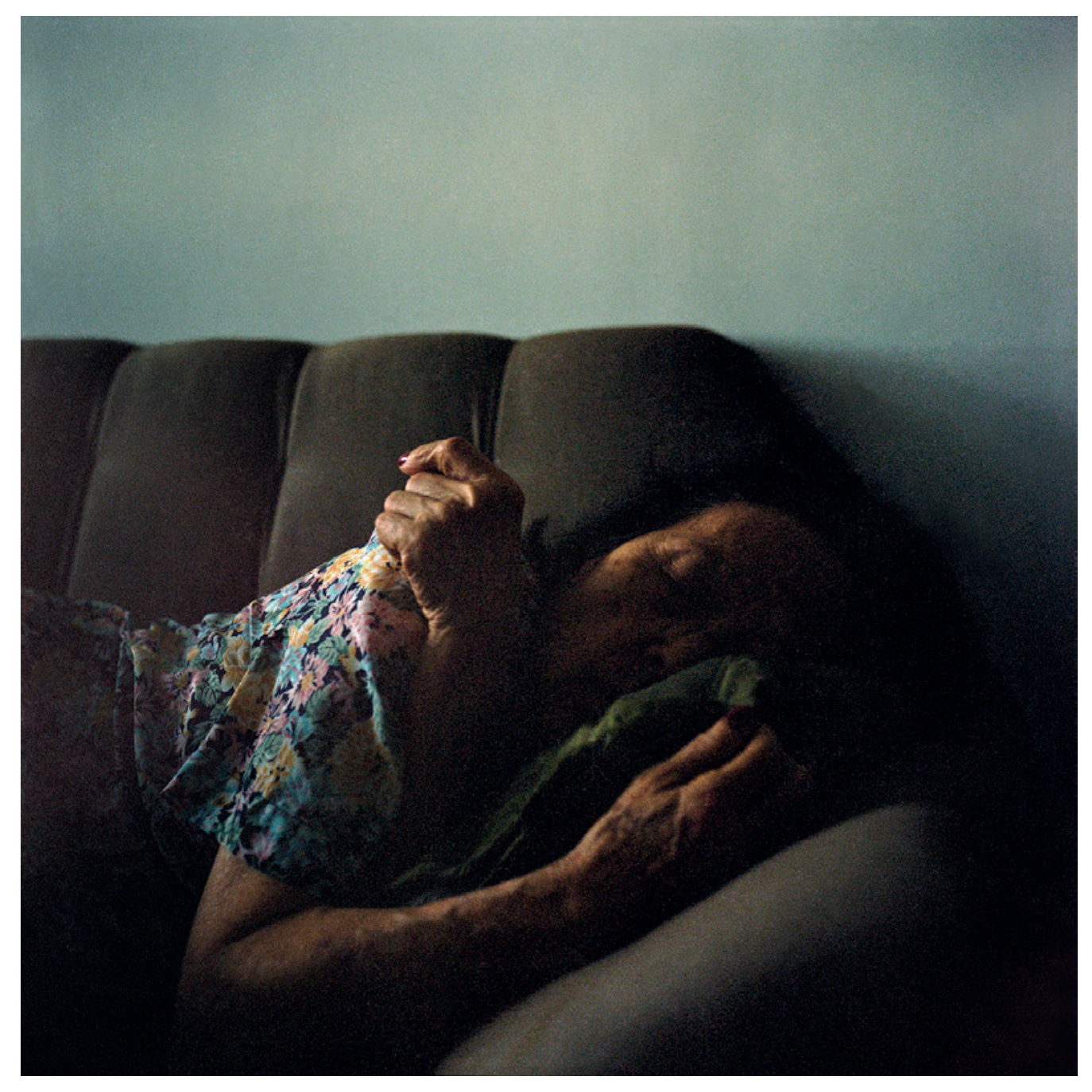




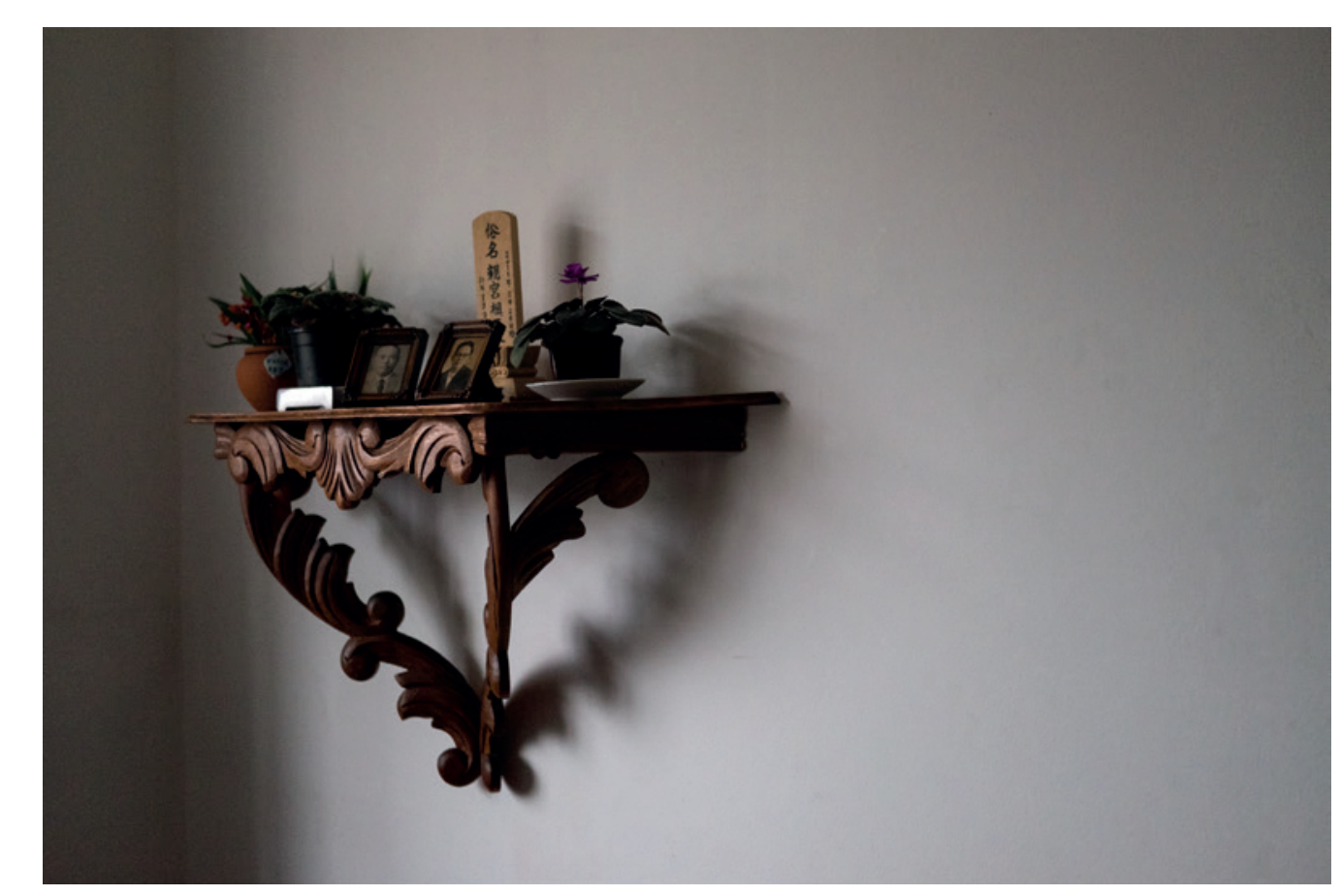



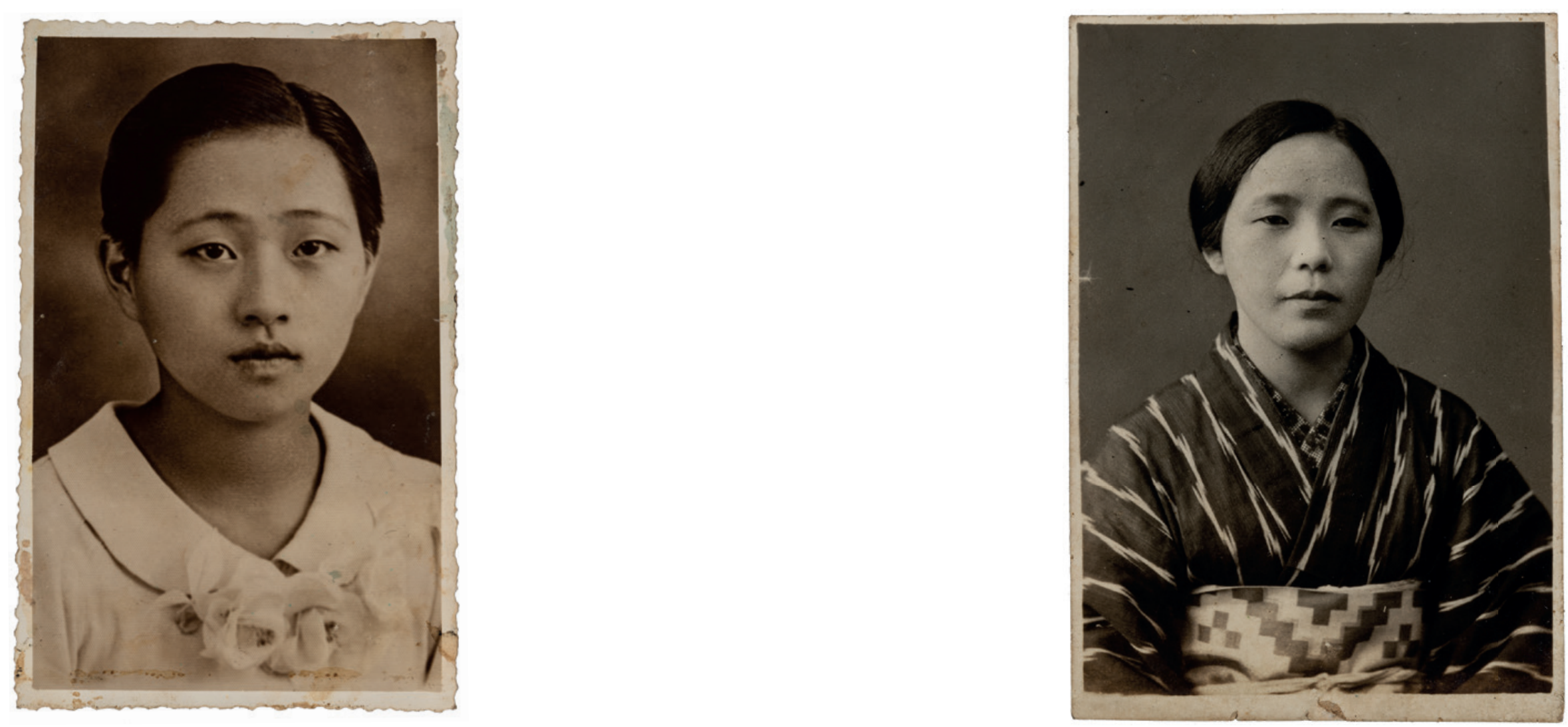


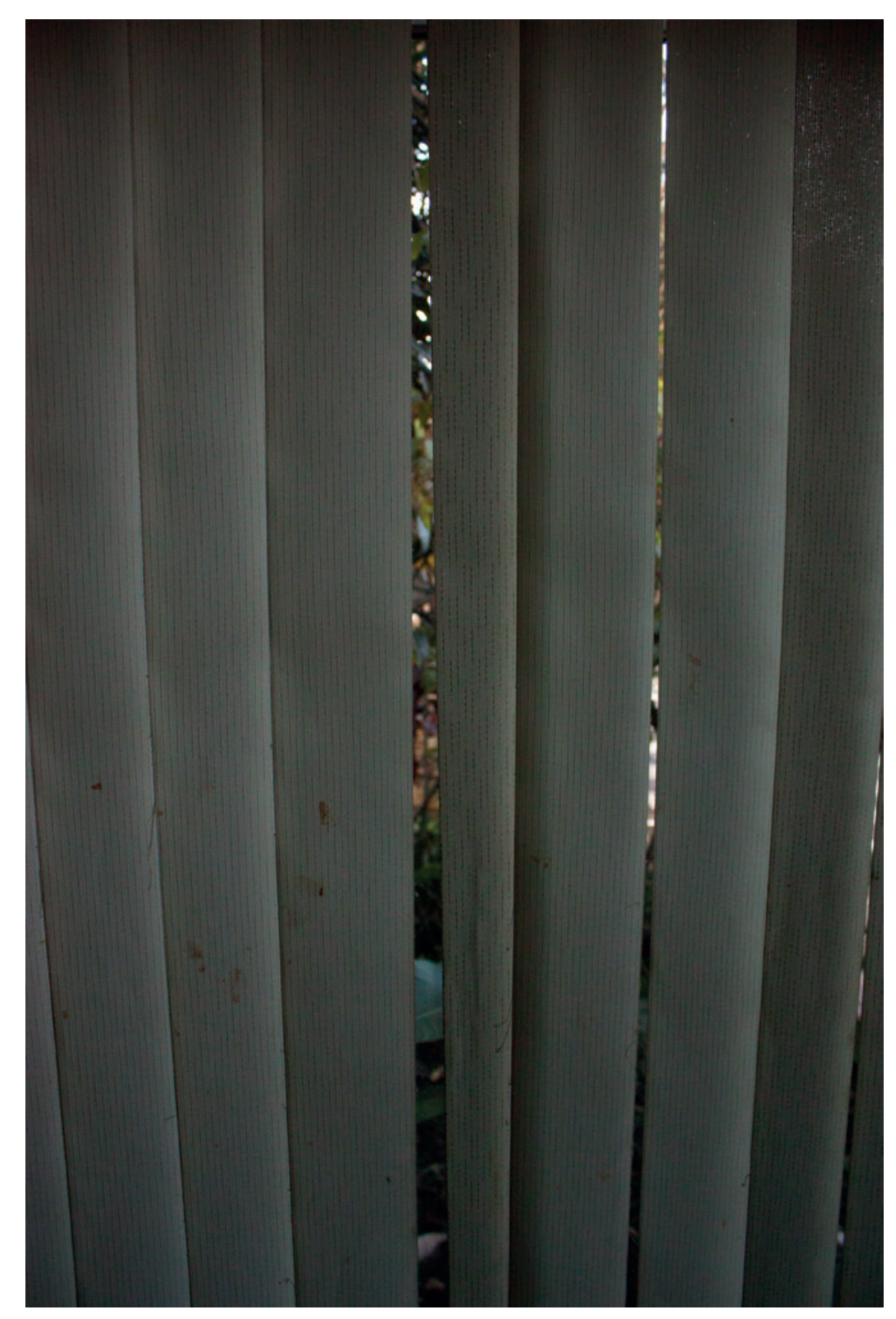





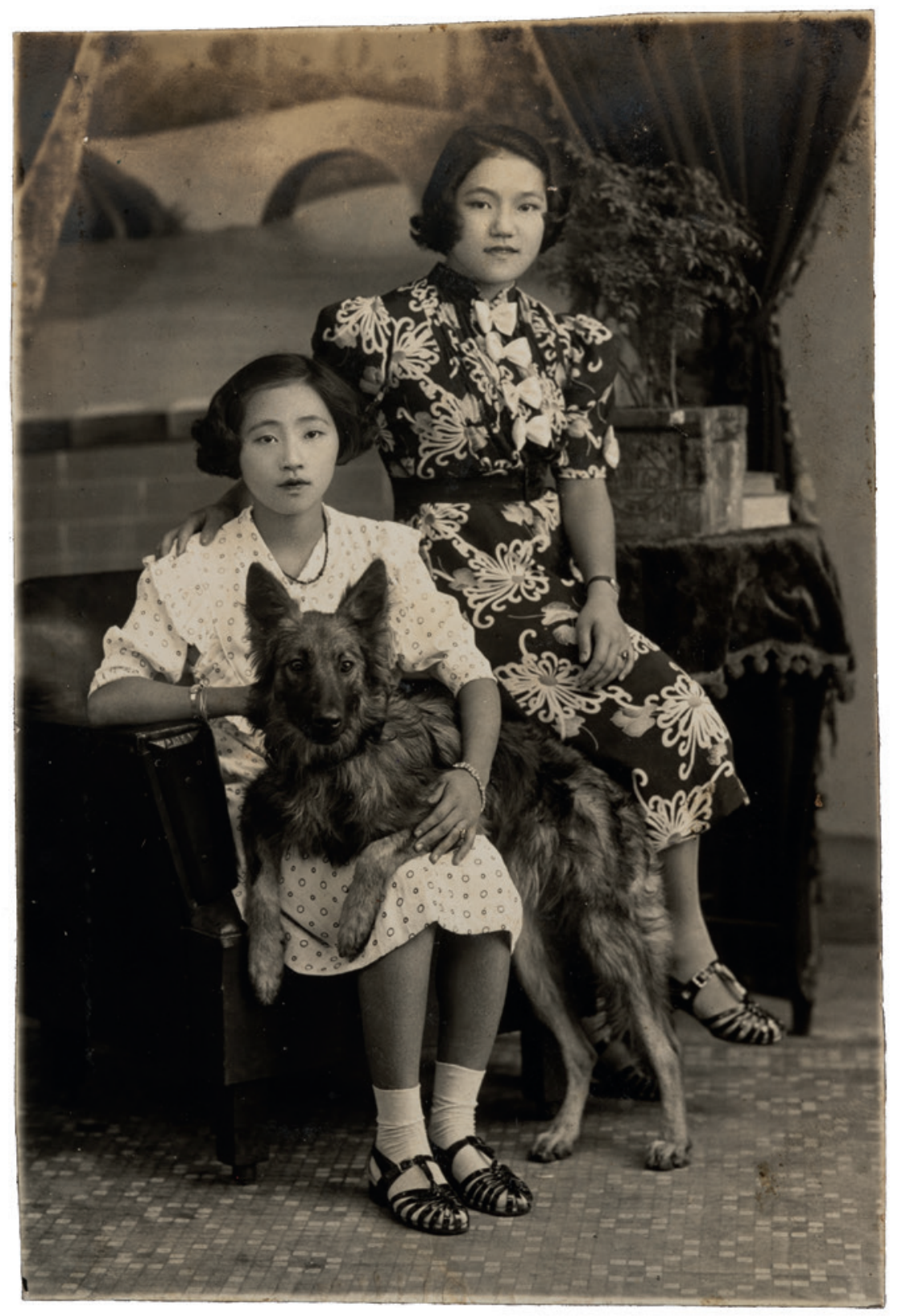




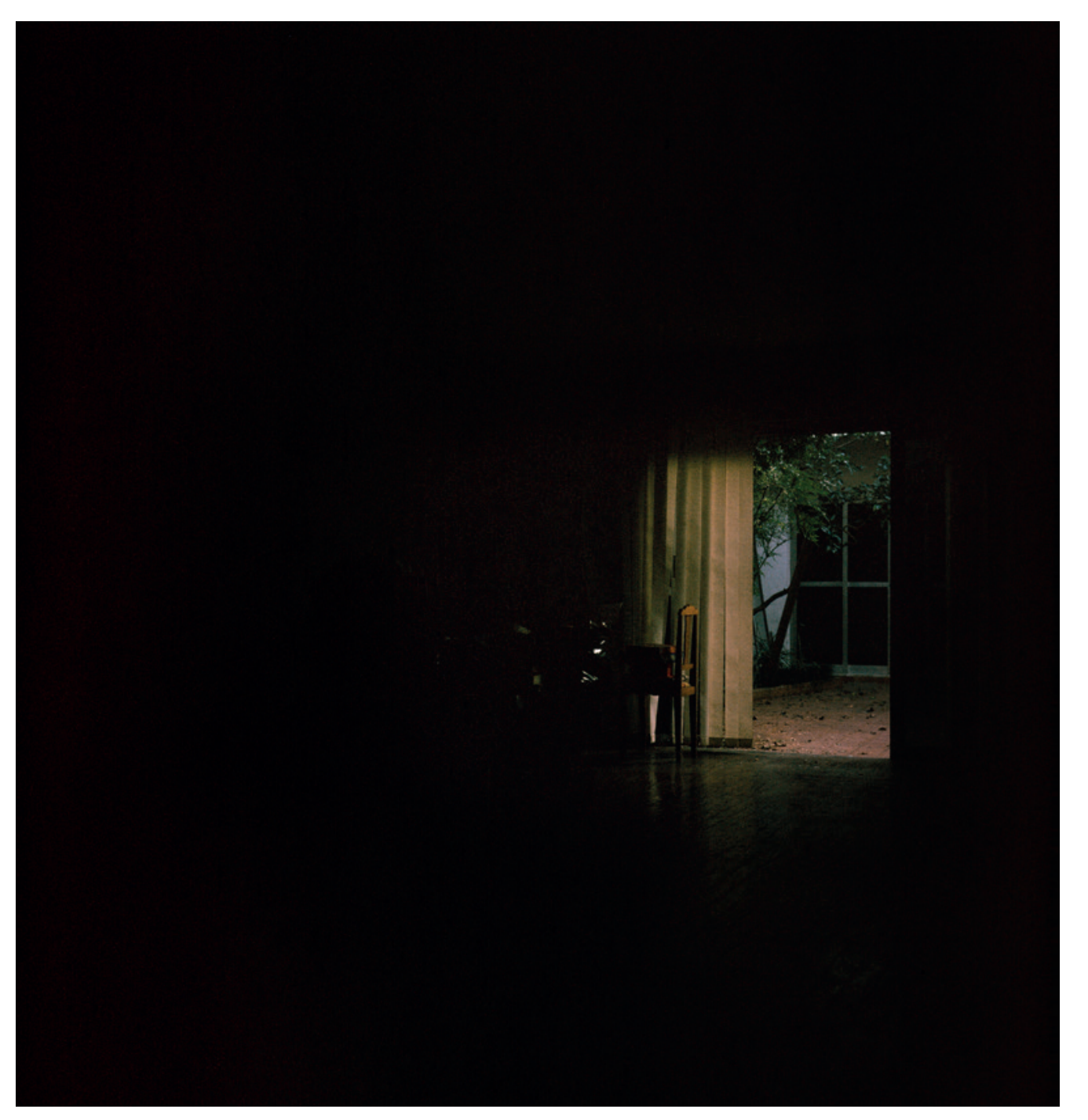




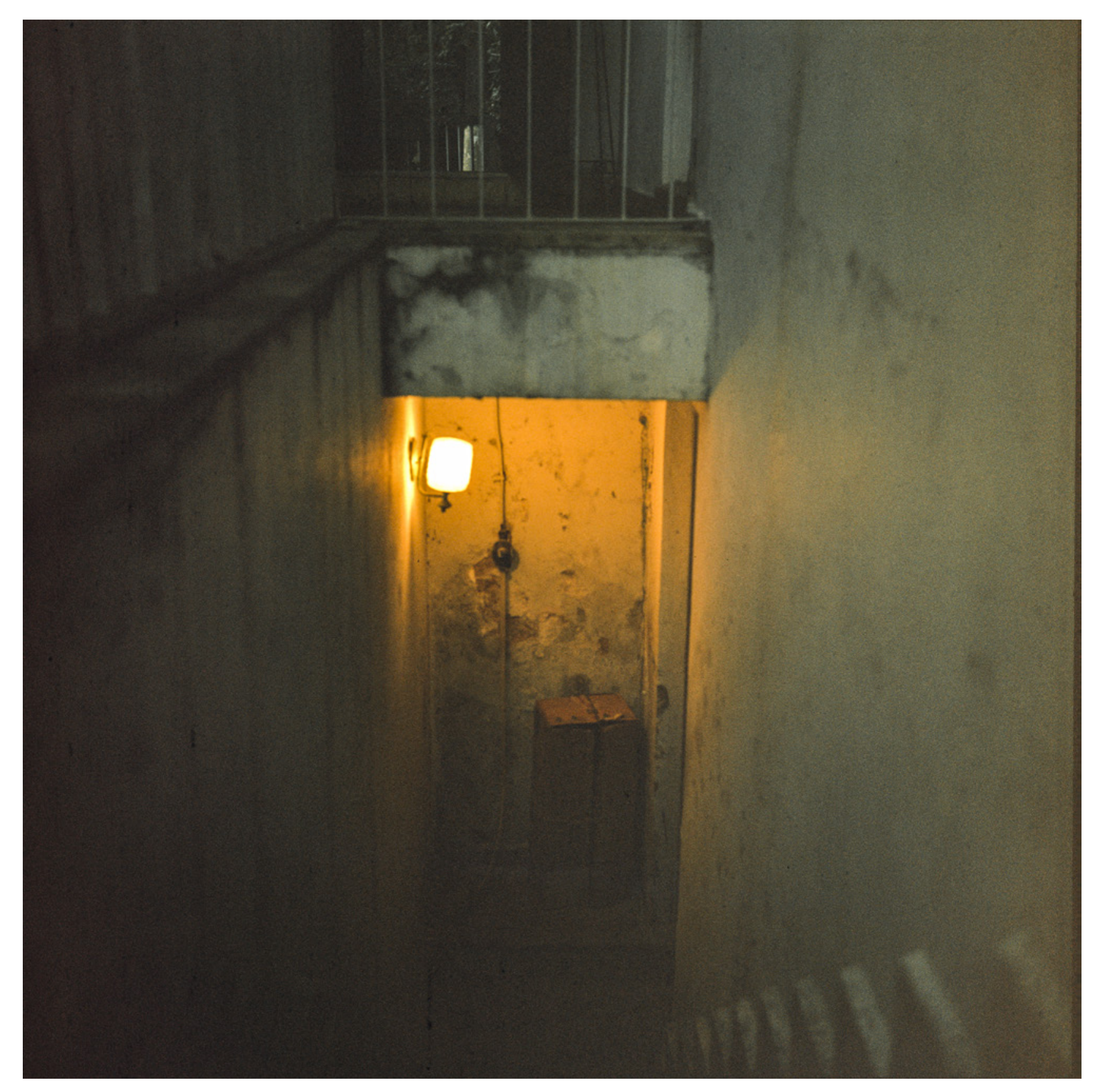




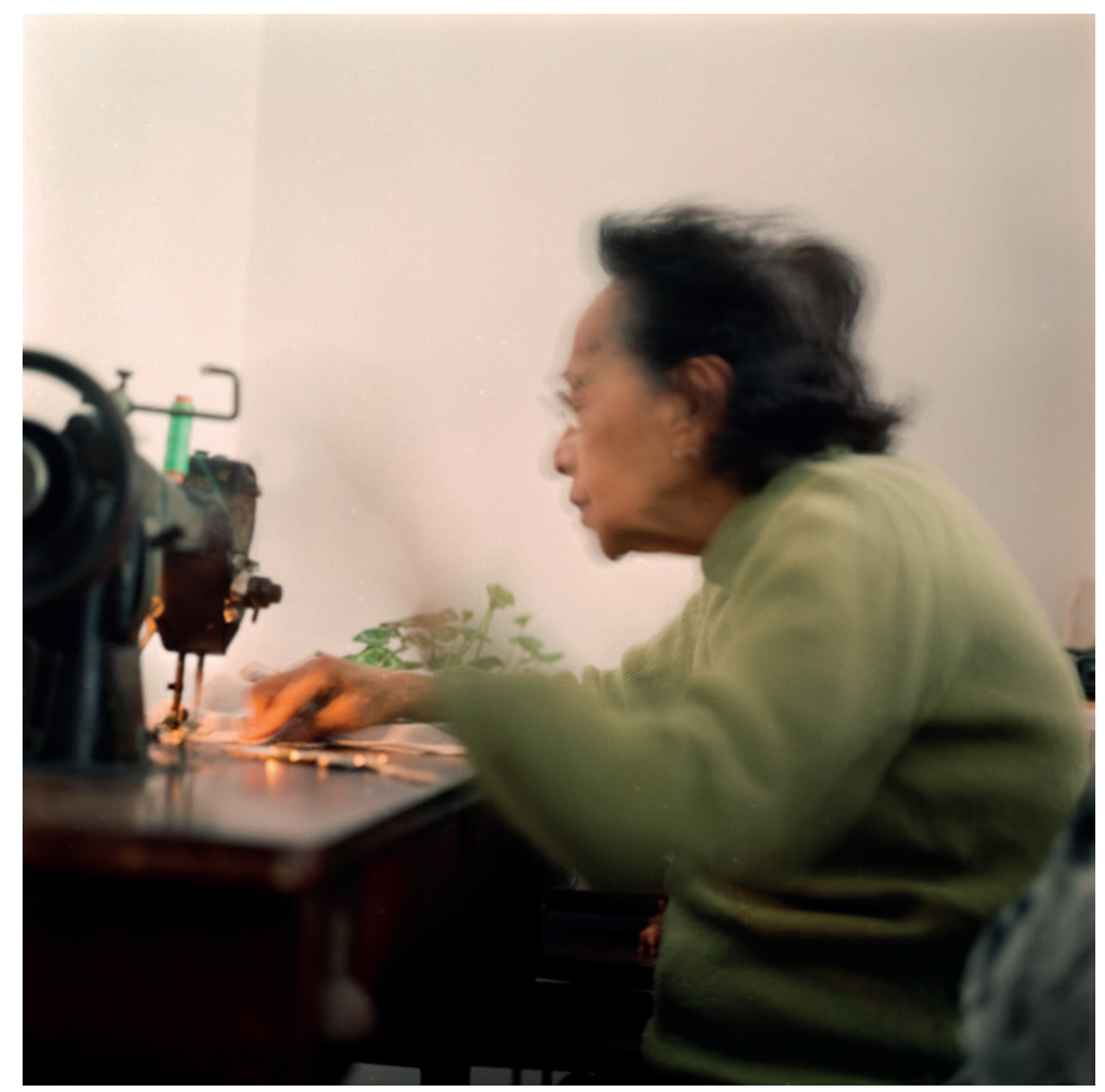




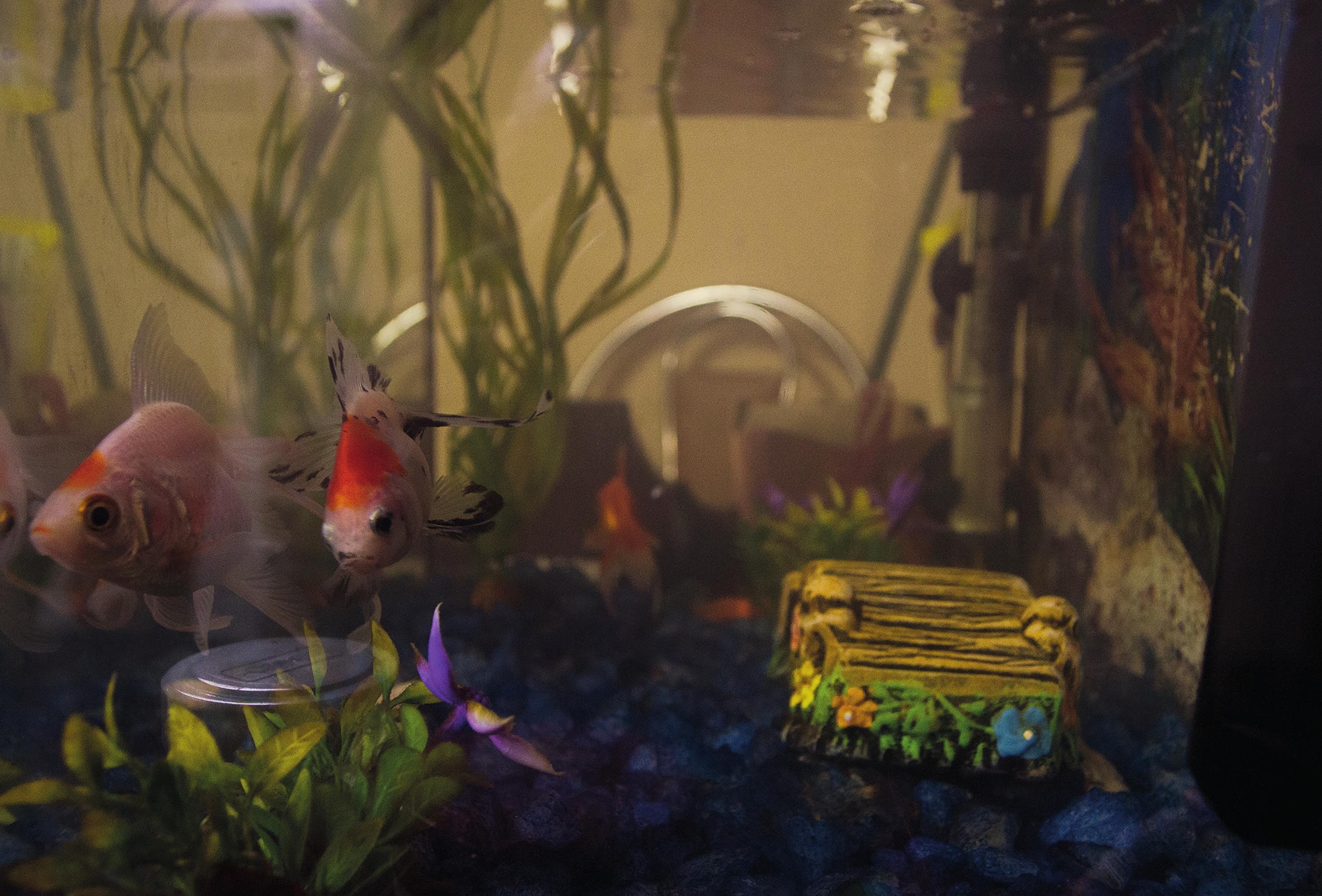




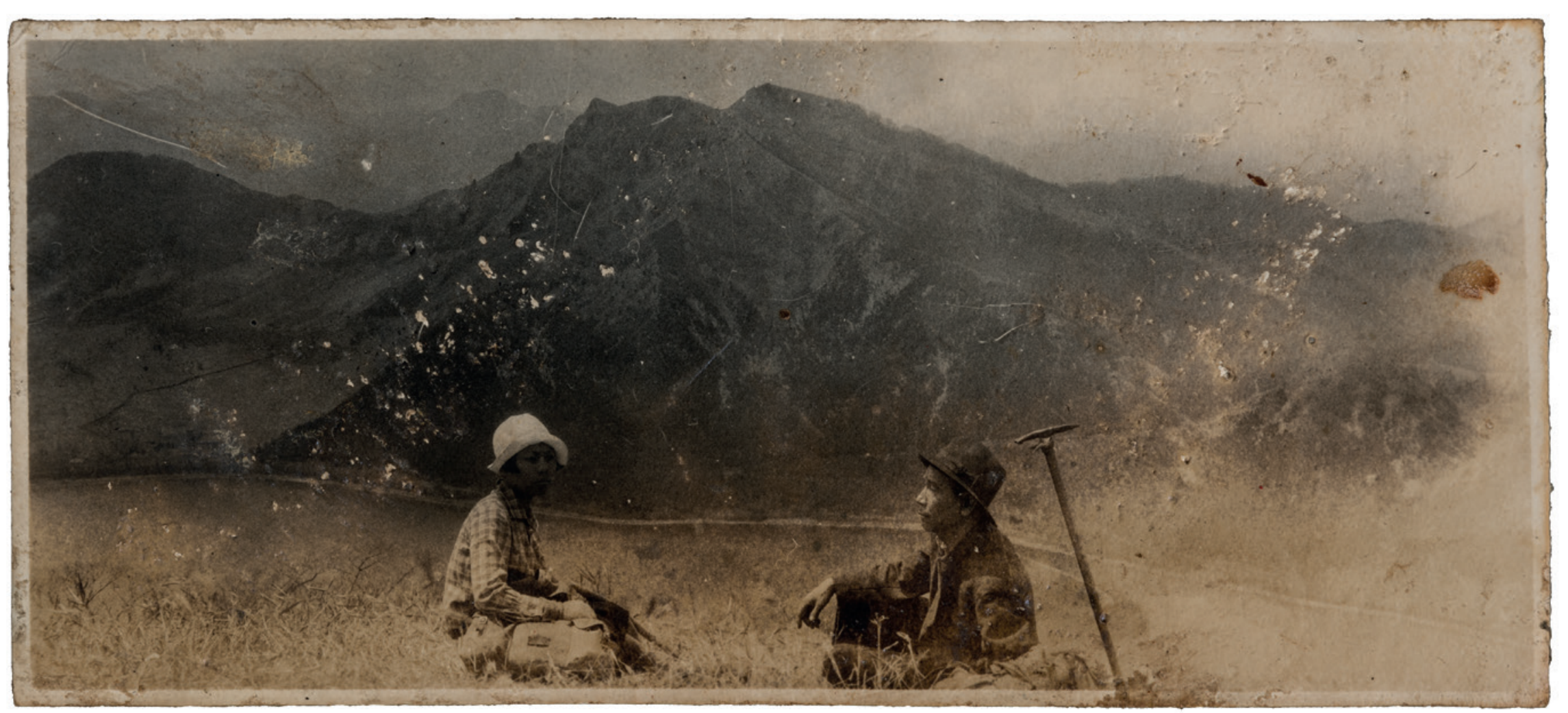




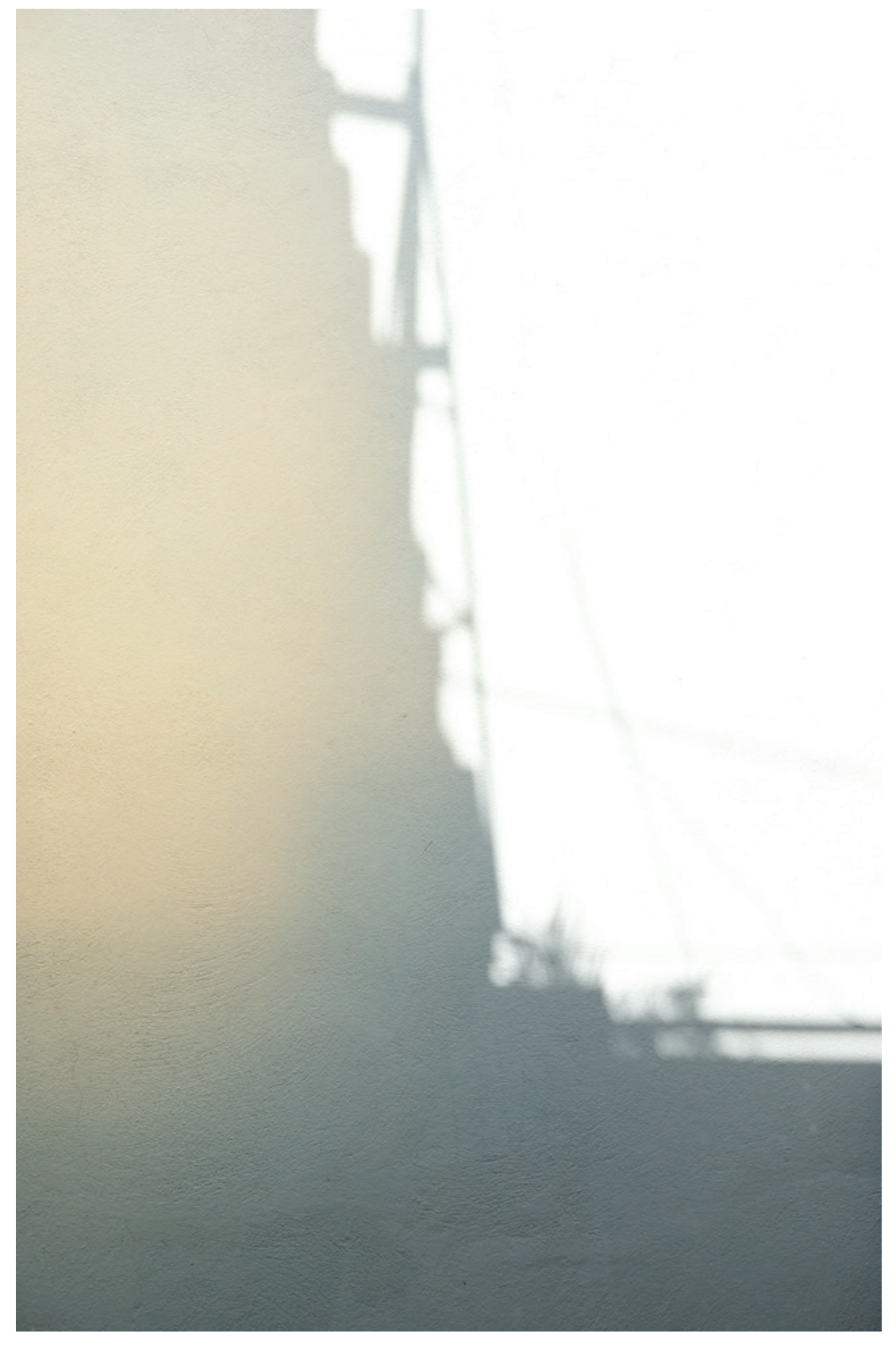




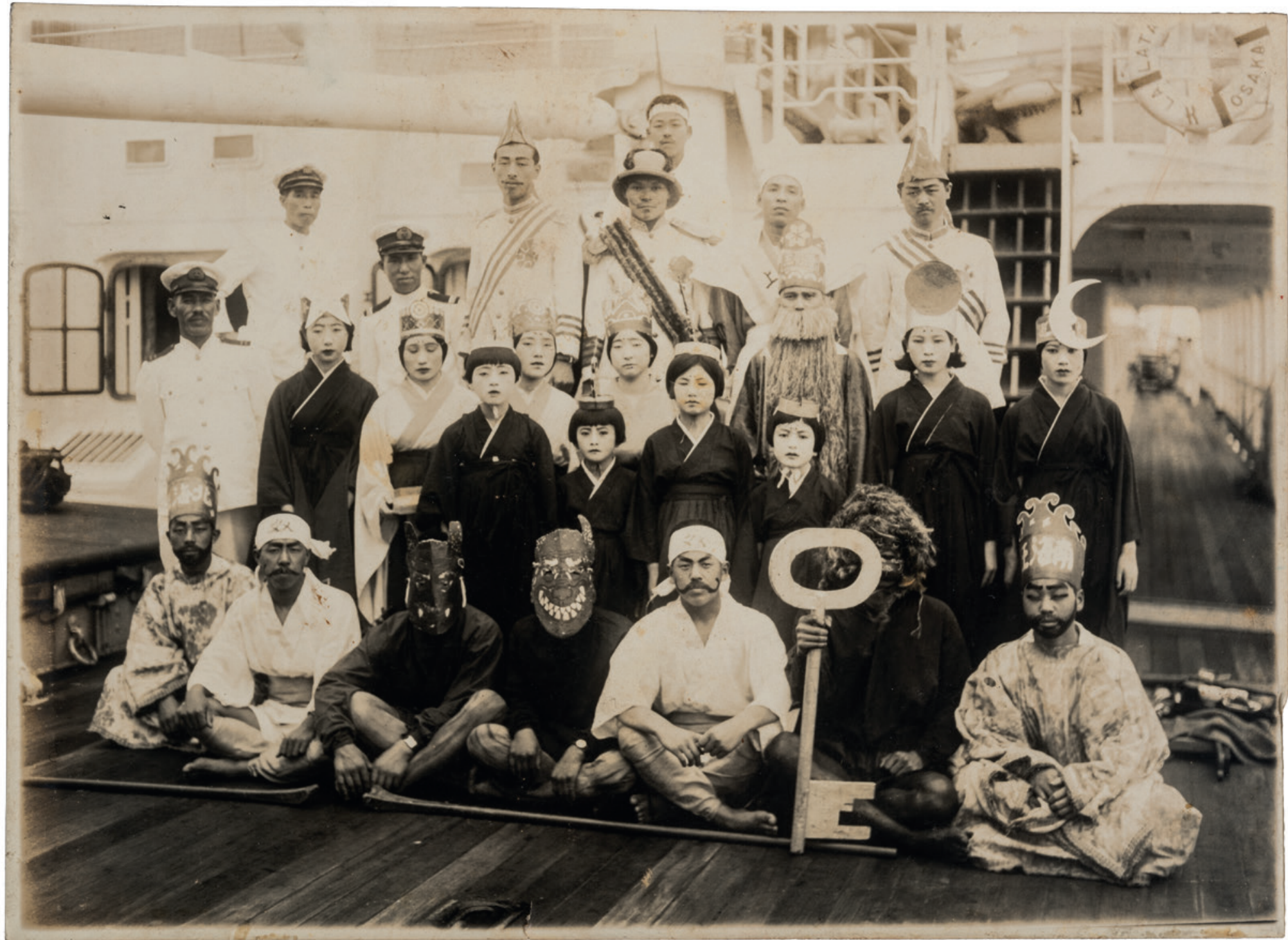




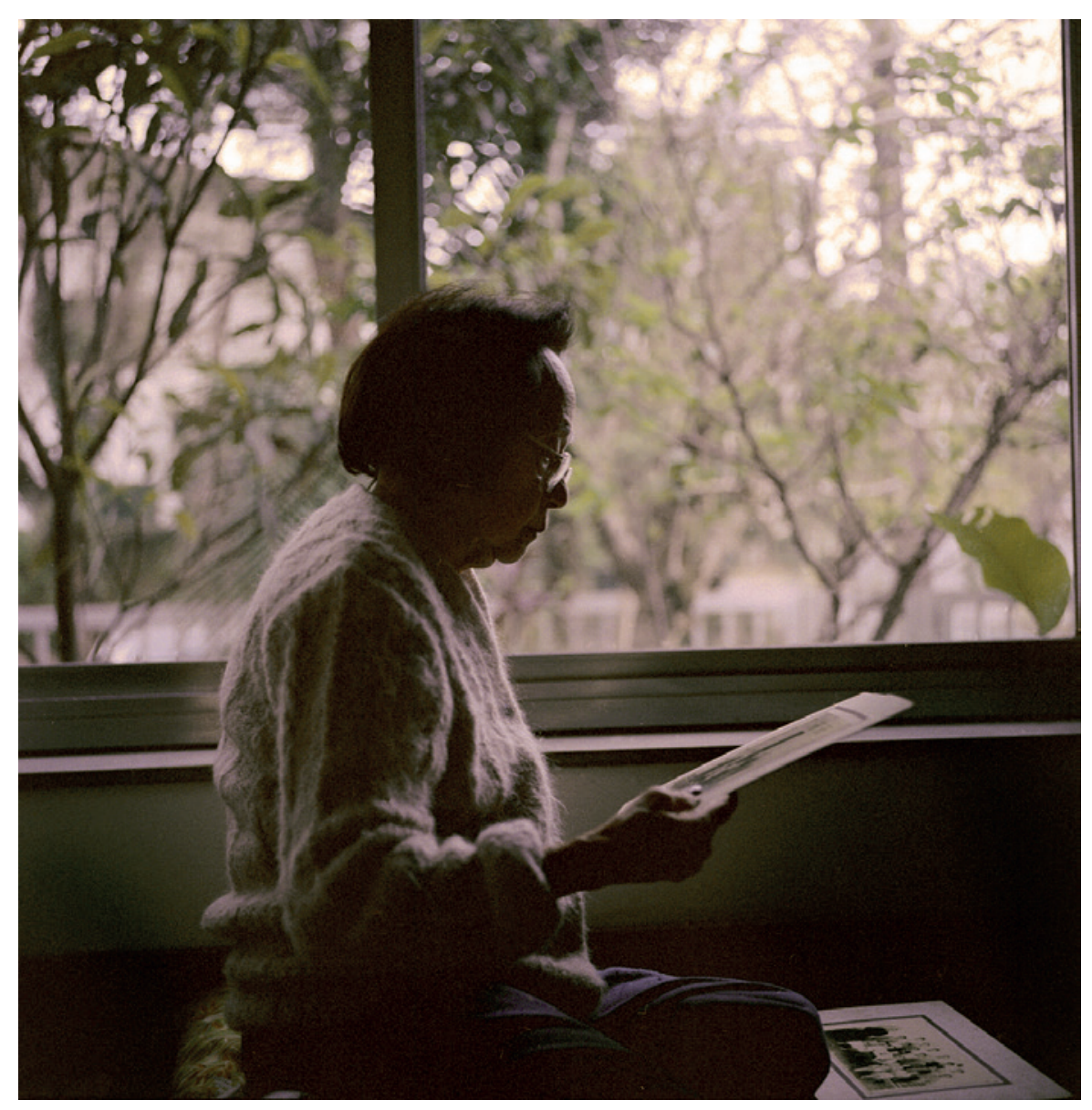




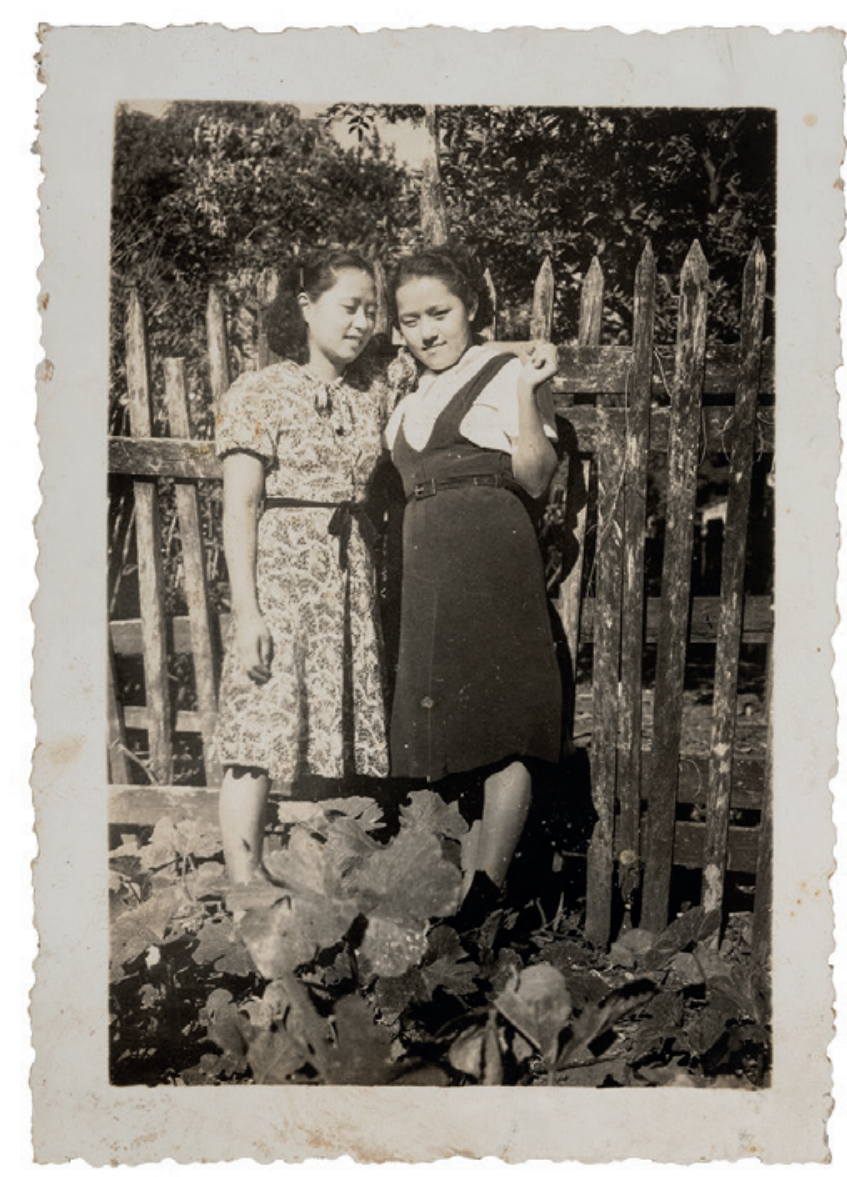



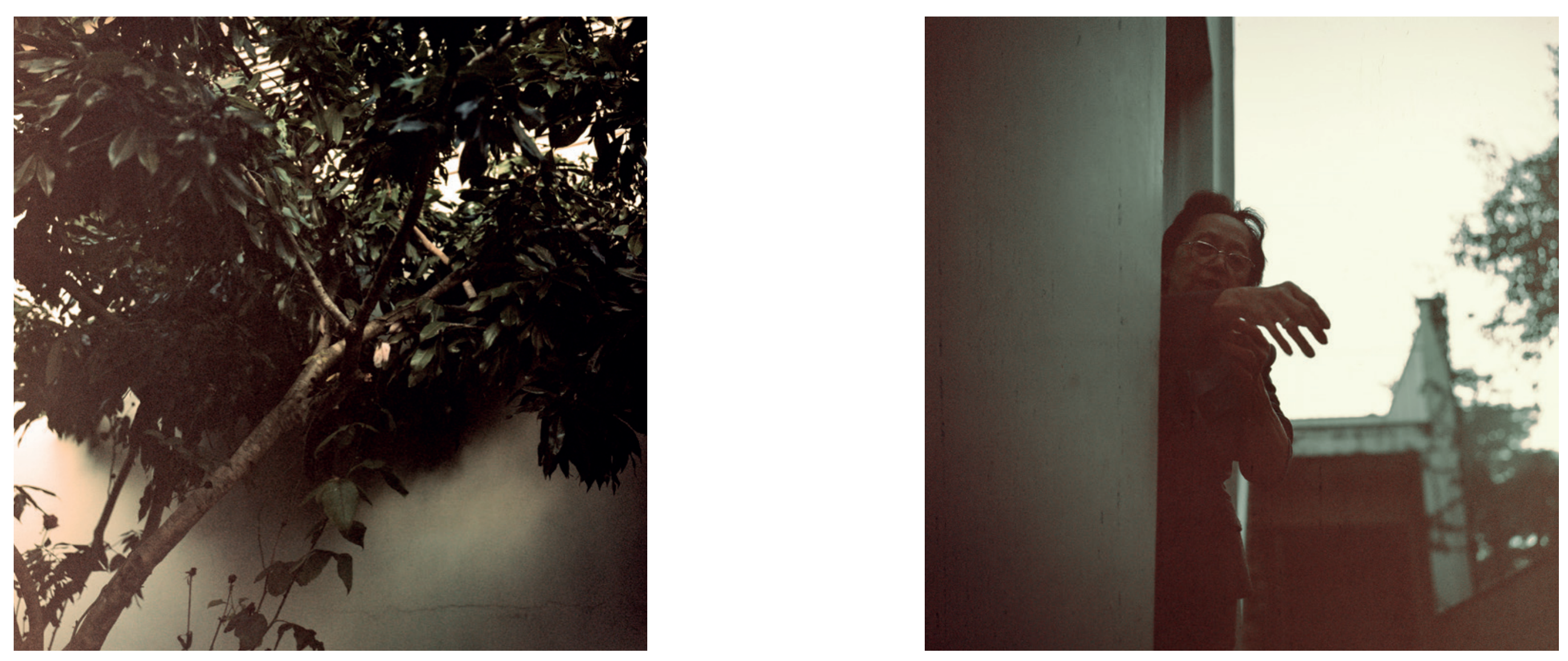


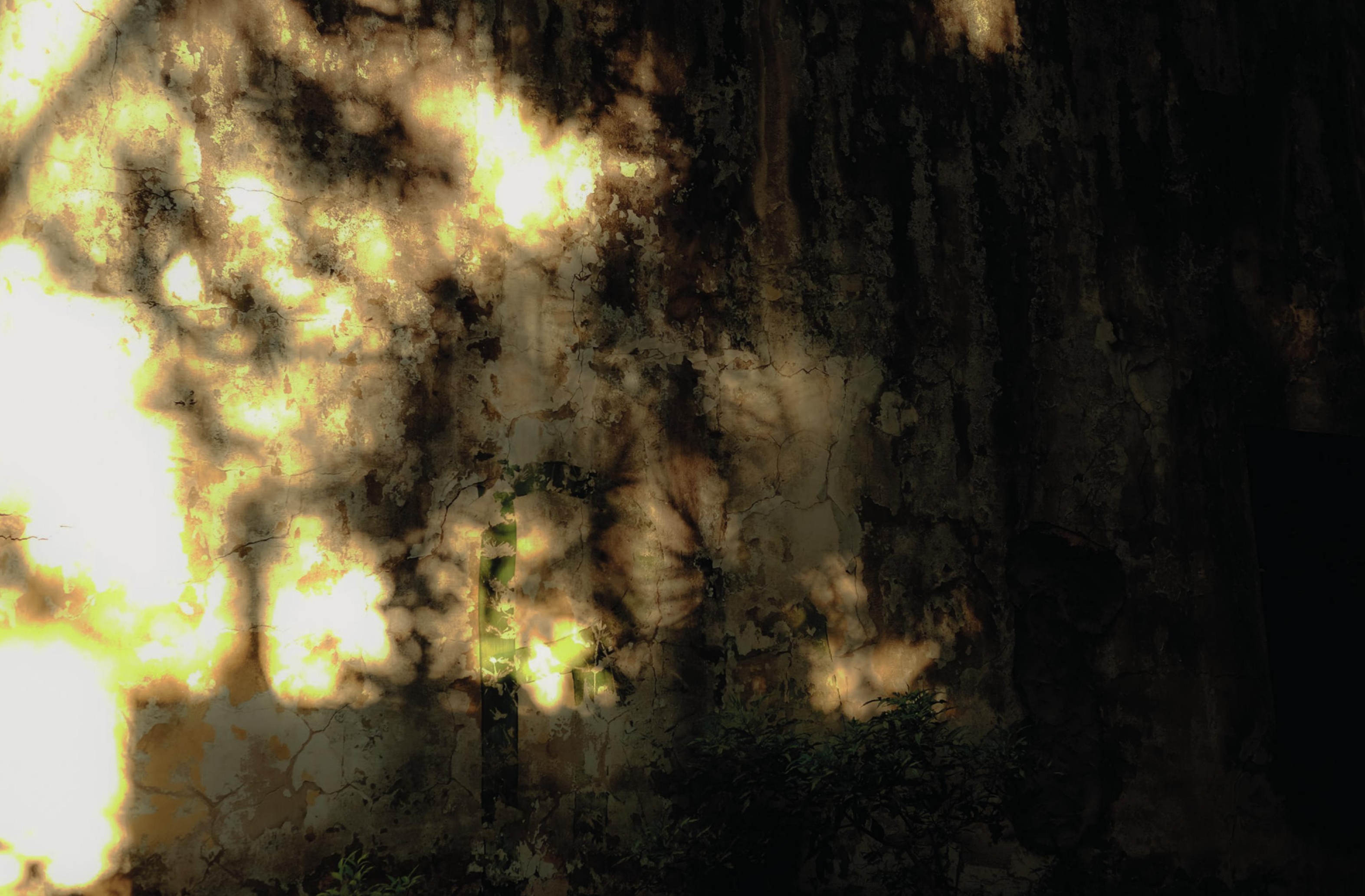




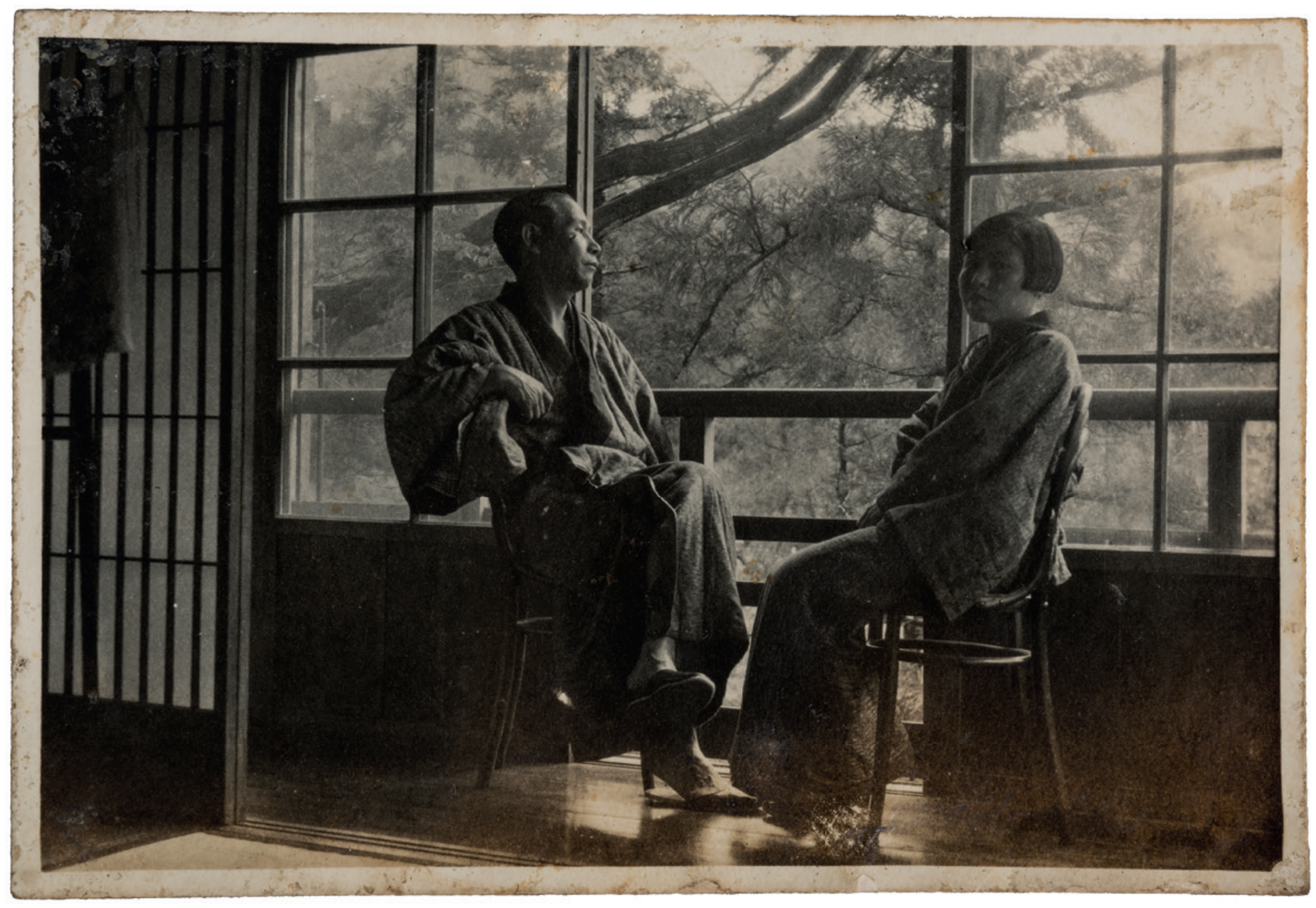




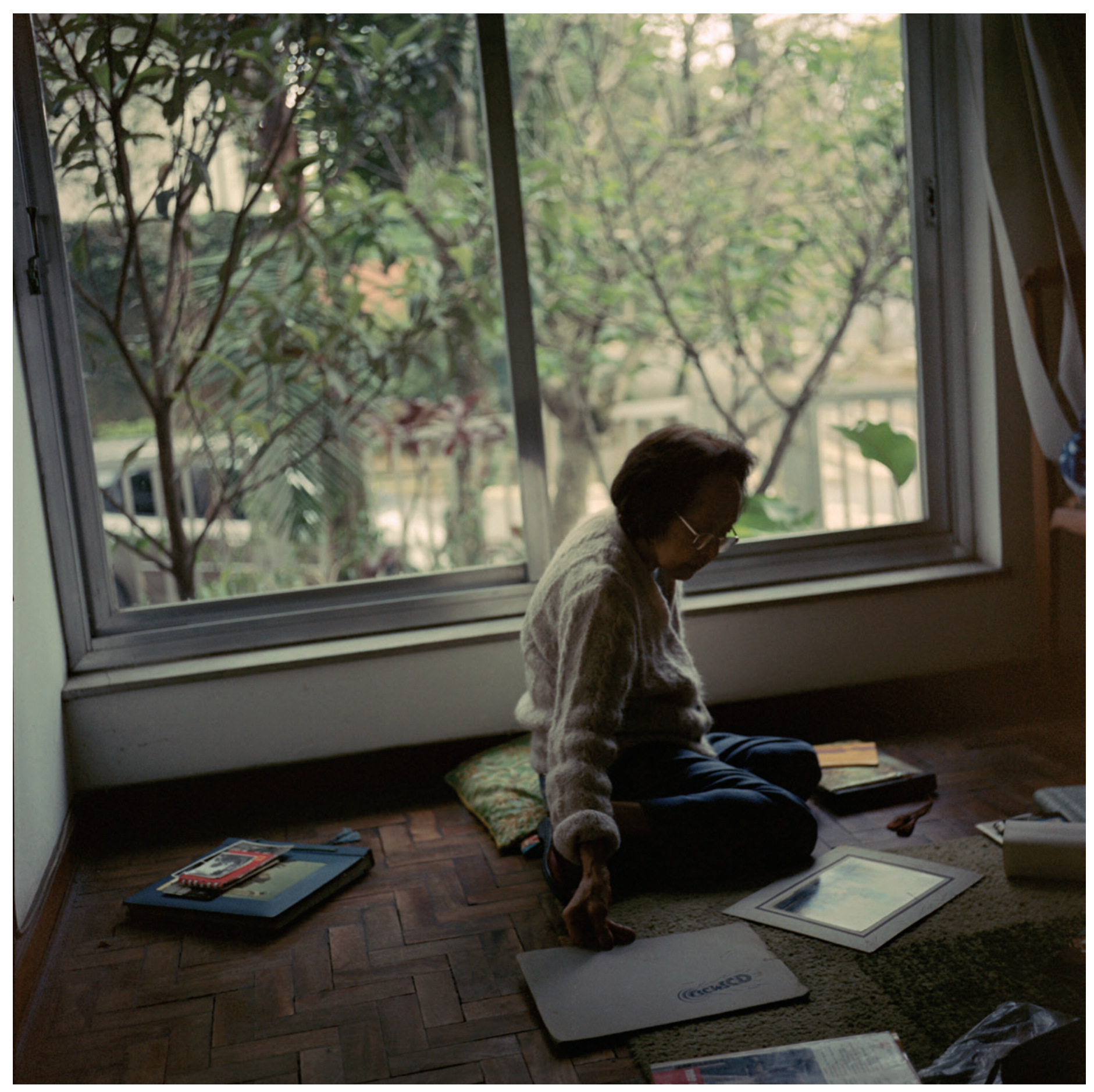




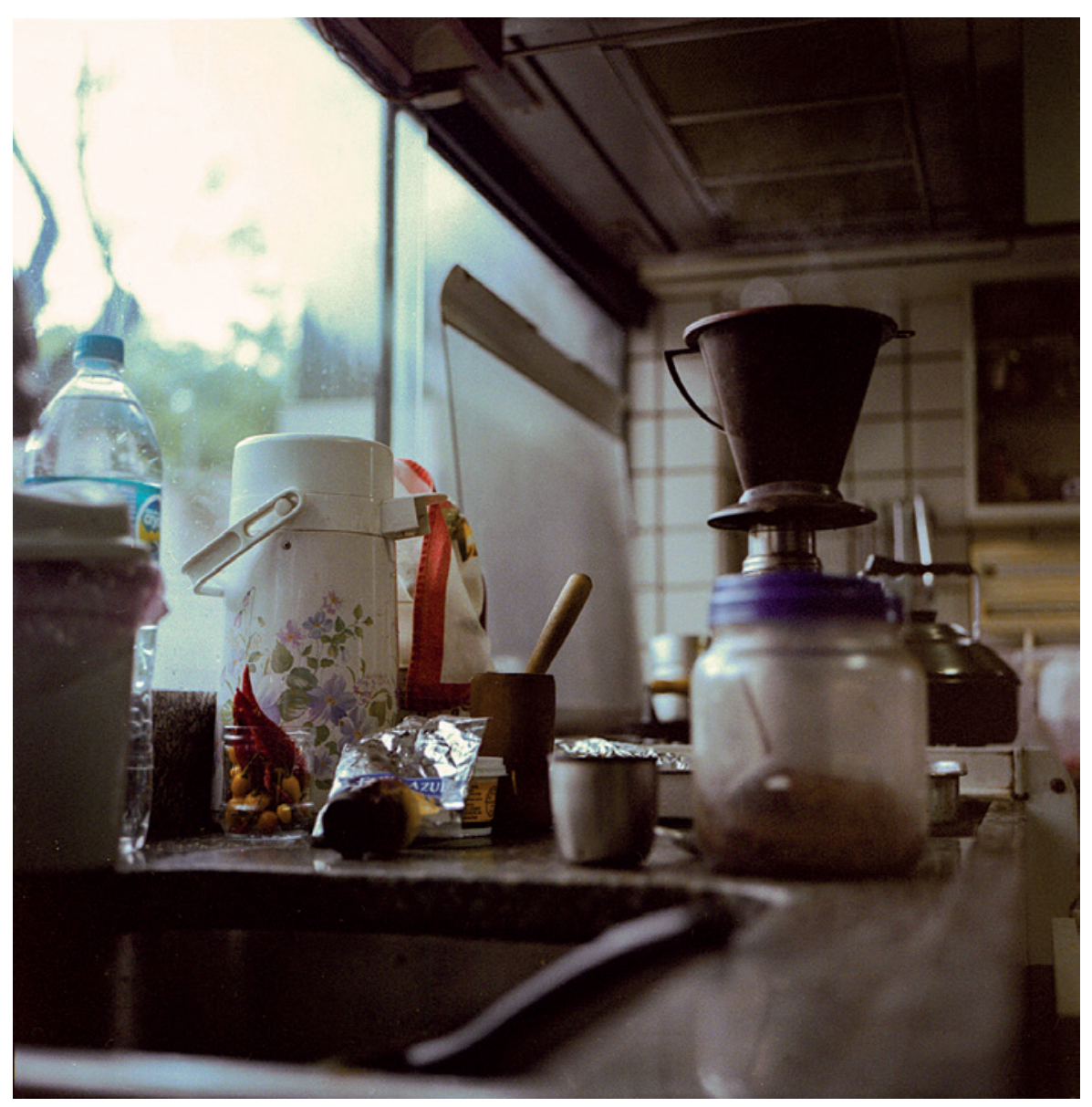



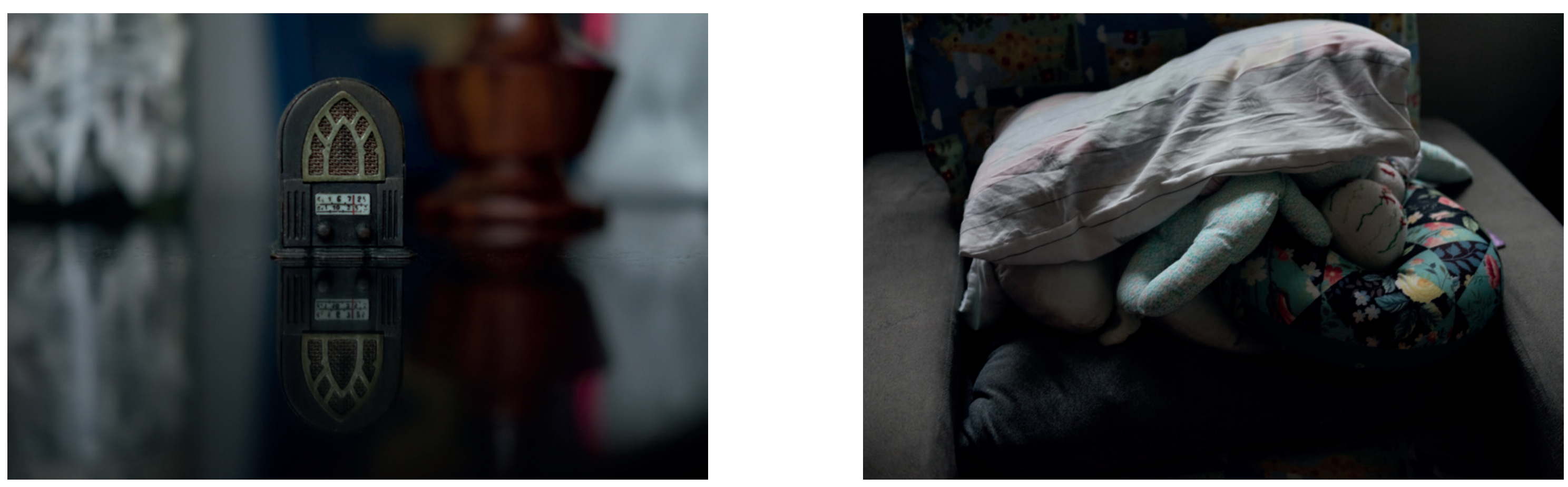


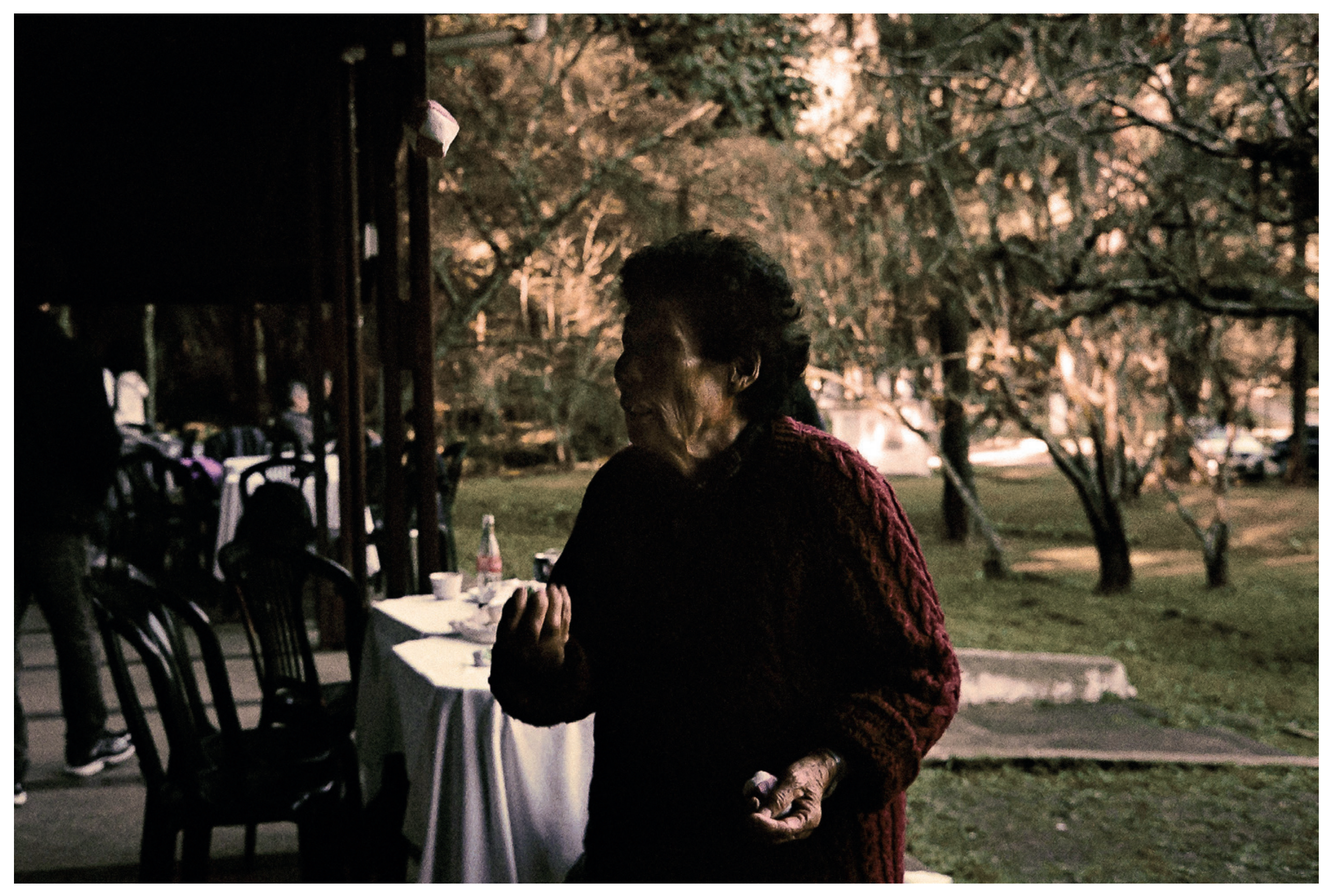


40

$3 \times 1 x^{2}$

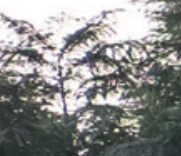

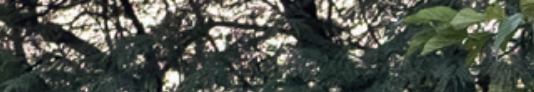

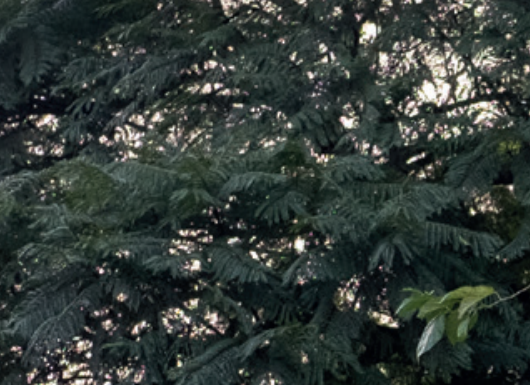

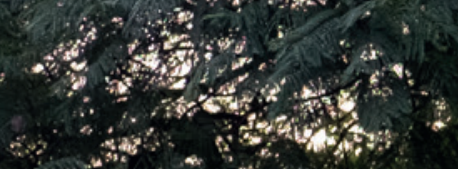

a. (2) +21
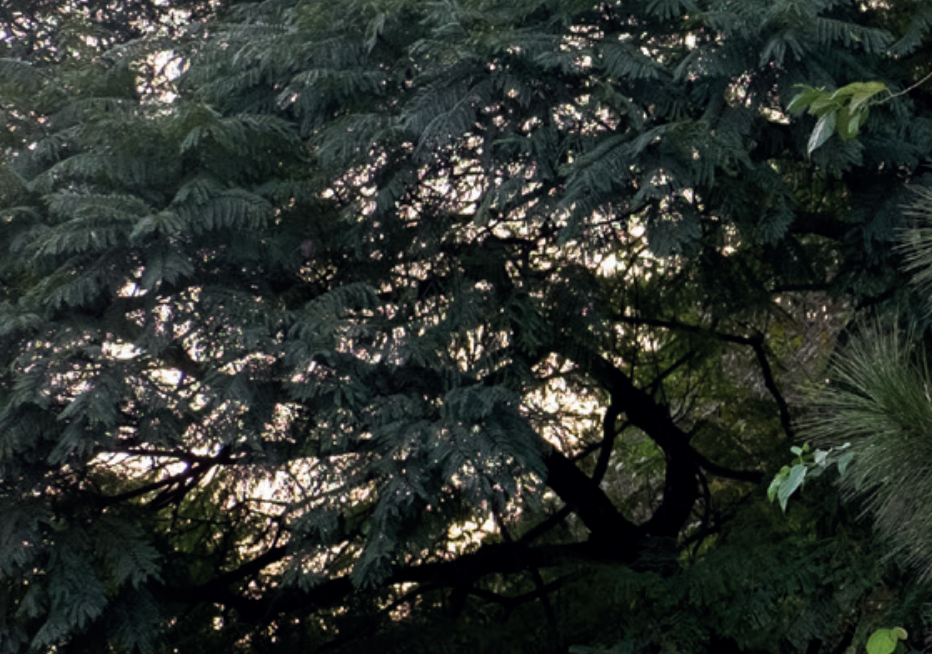

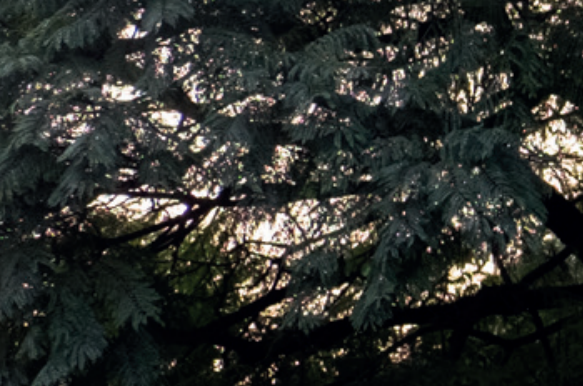

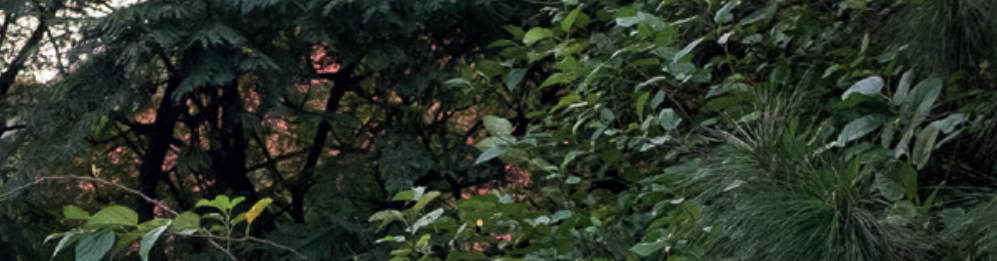

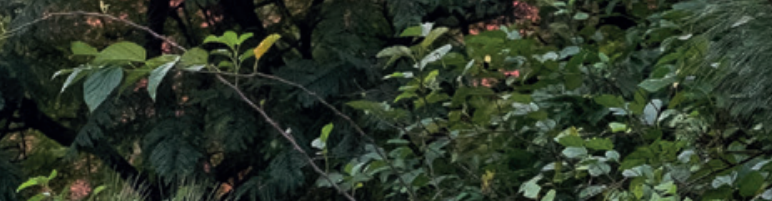

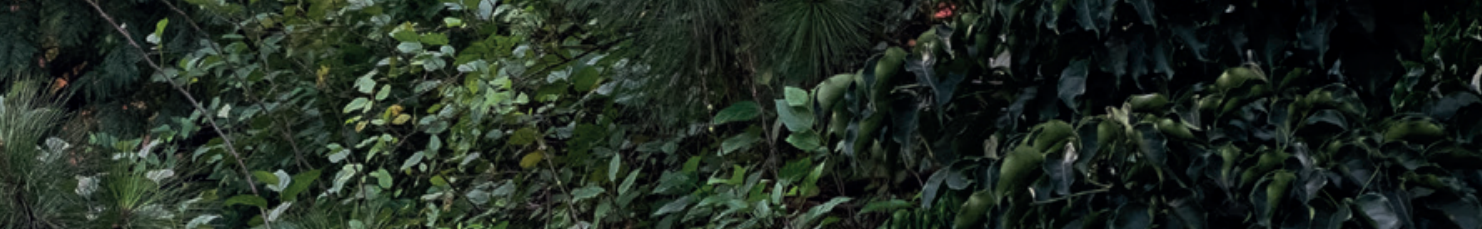

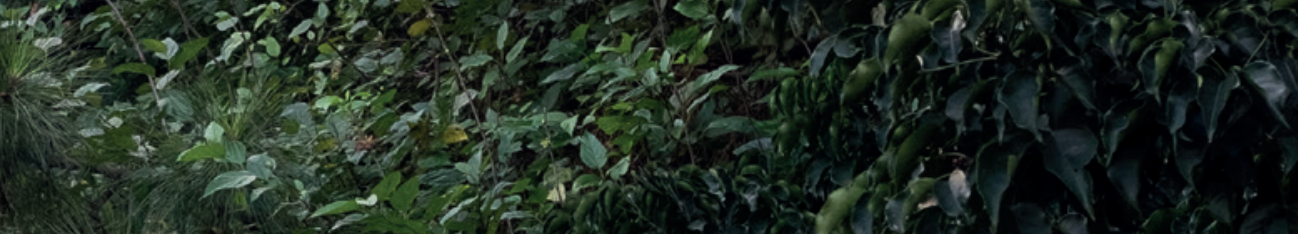

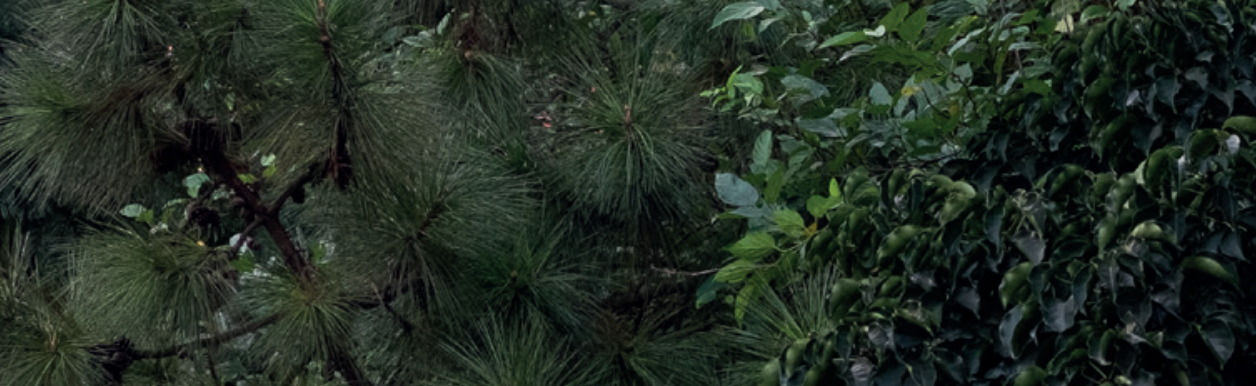

$201-1$

10

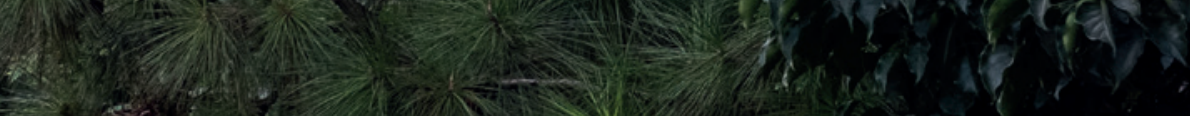

(n) $2 x^{4}+y^{2}$

3.)
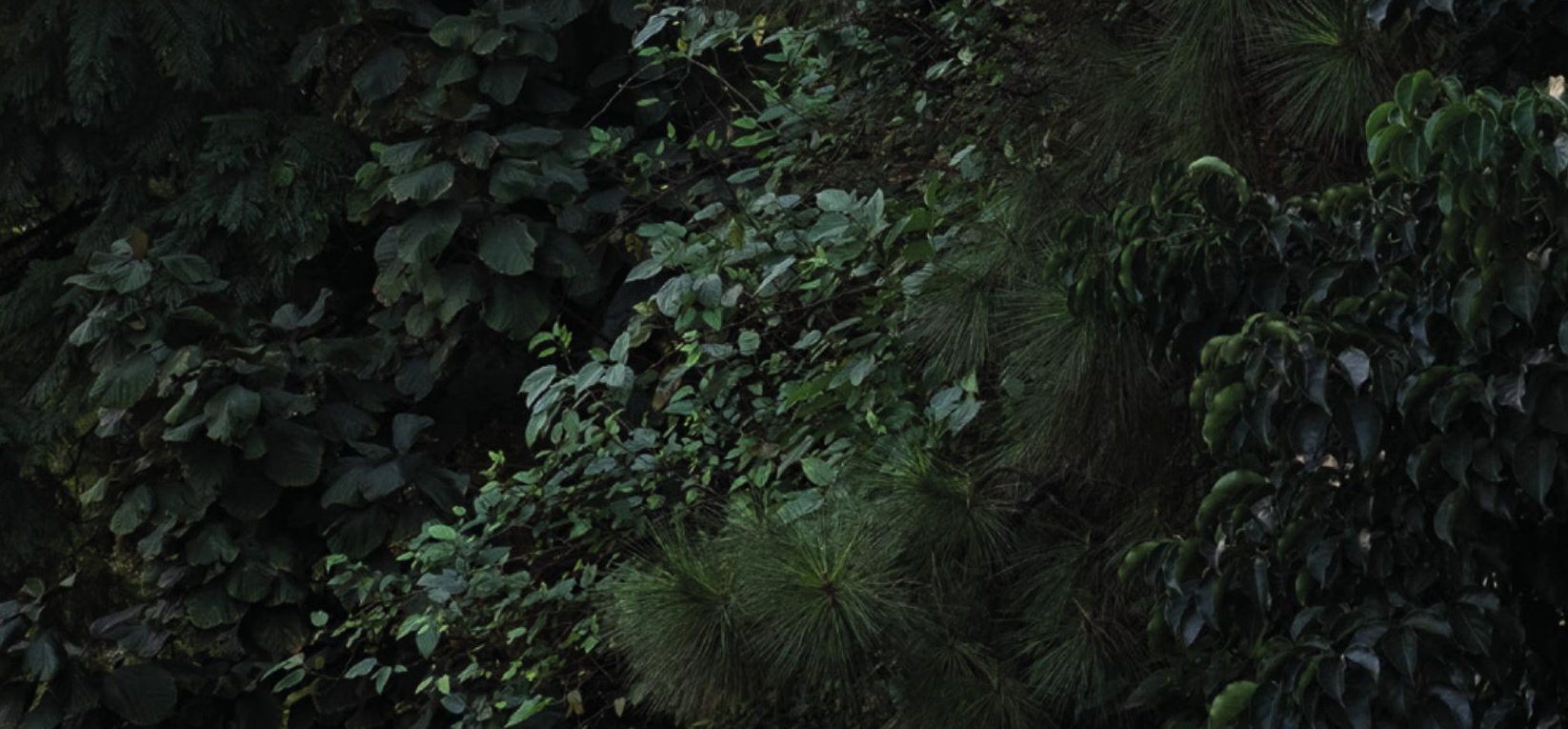


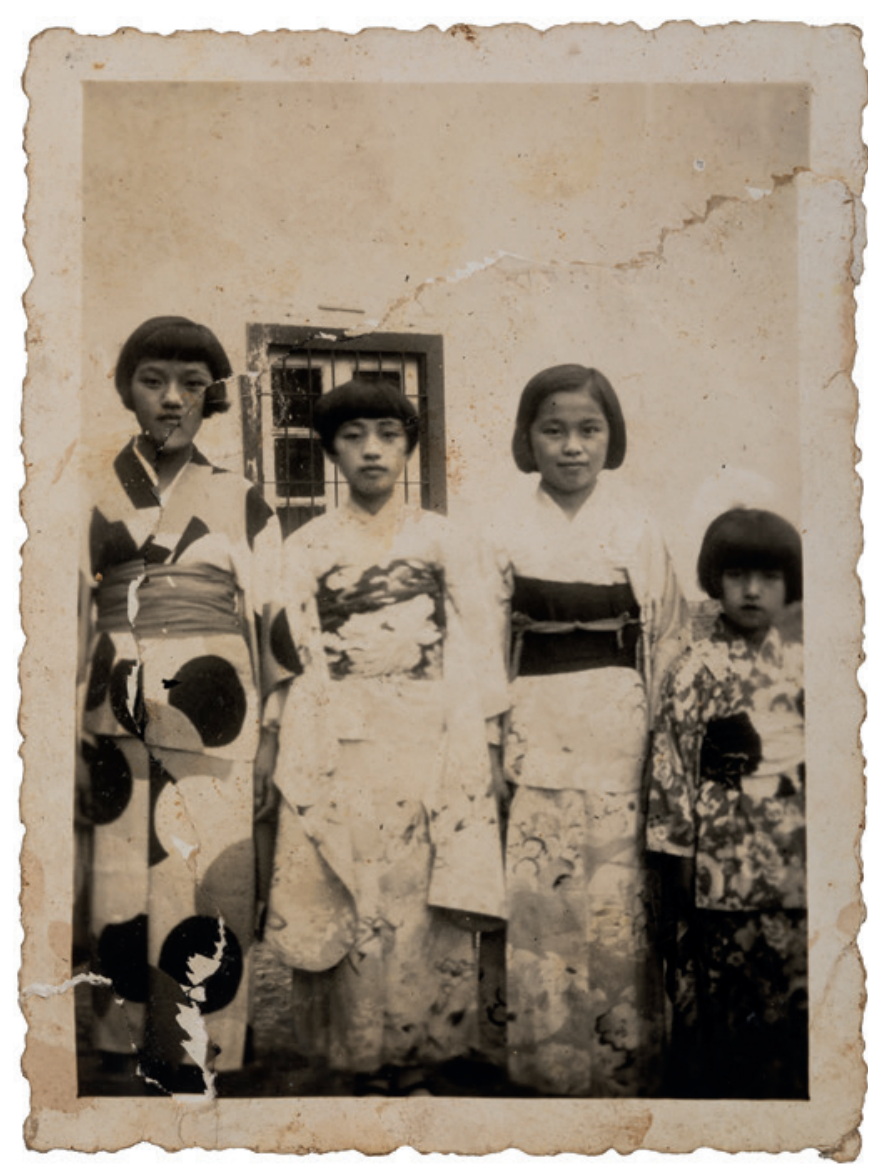




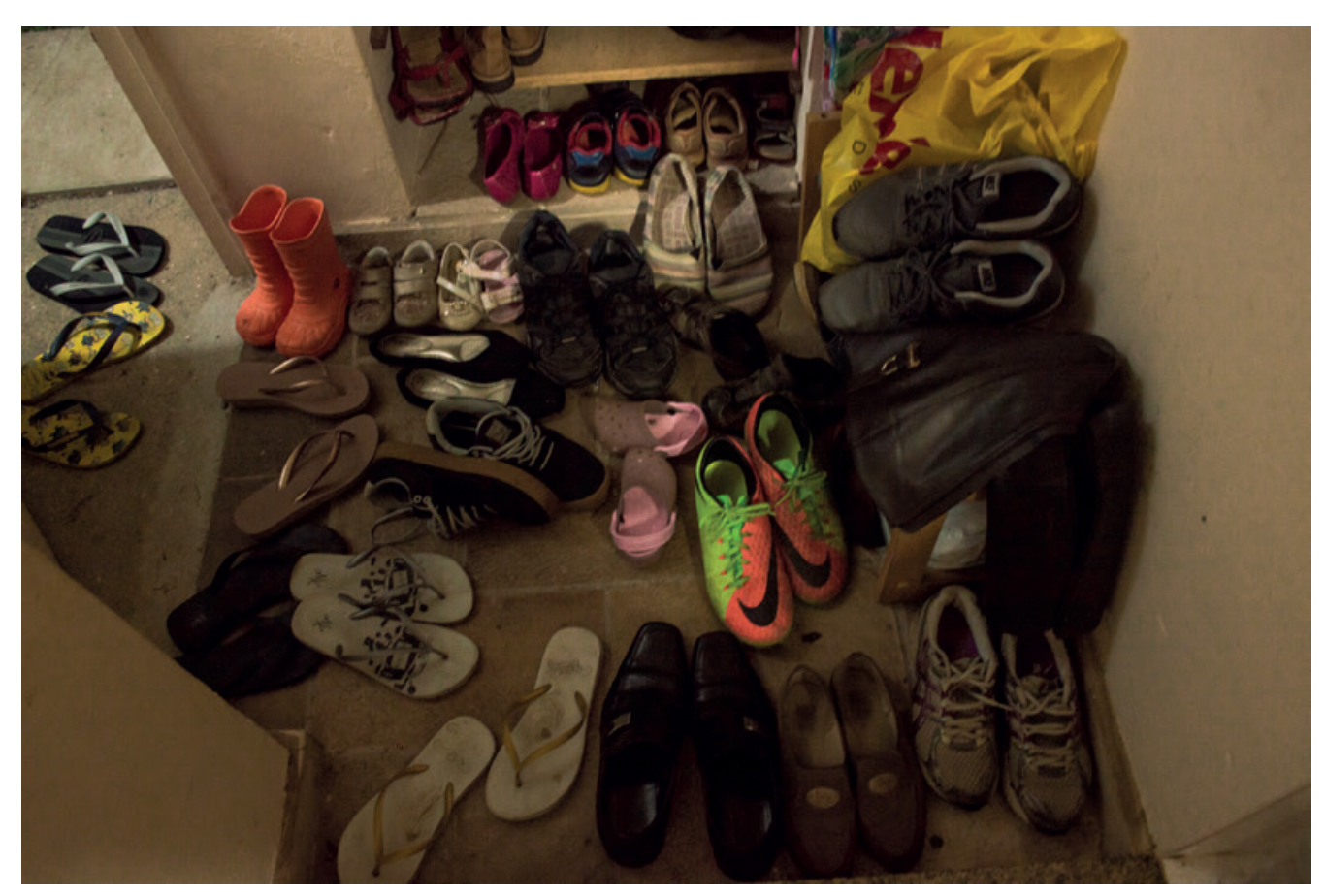




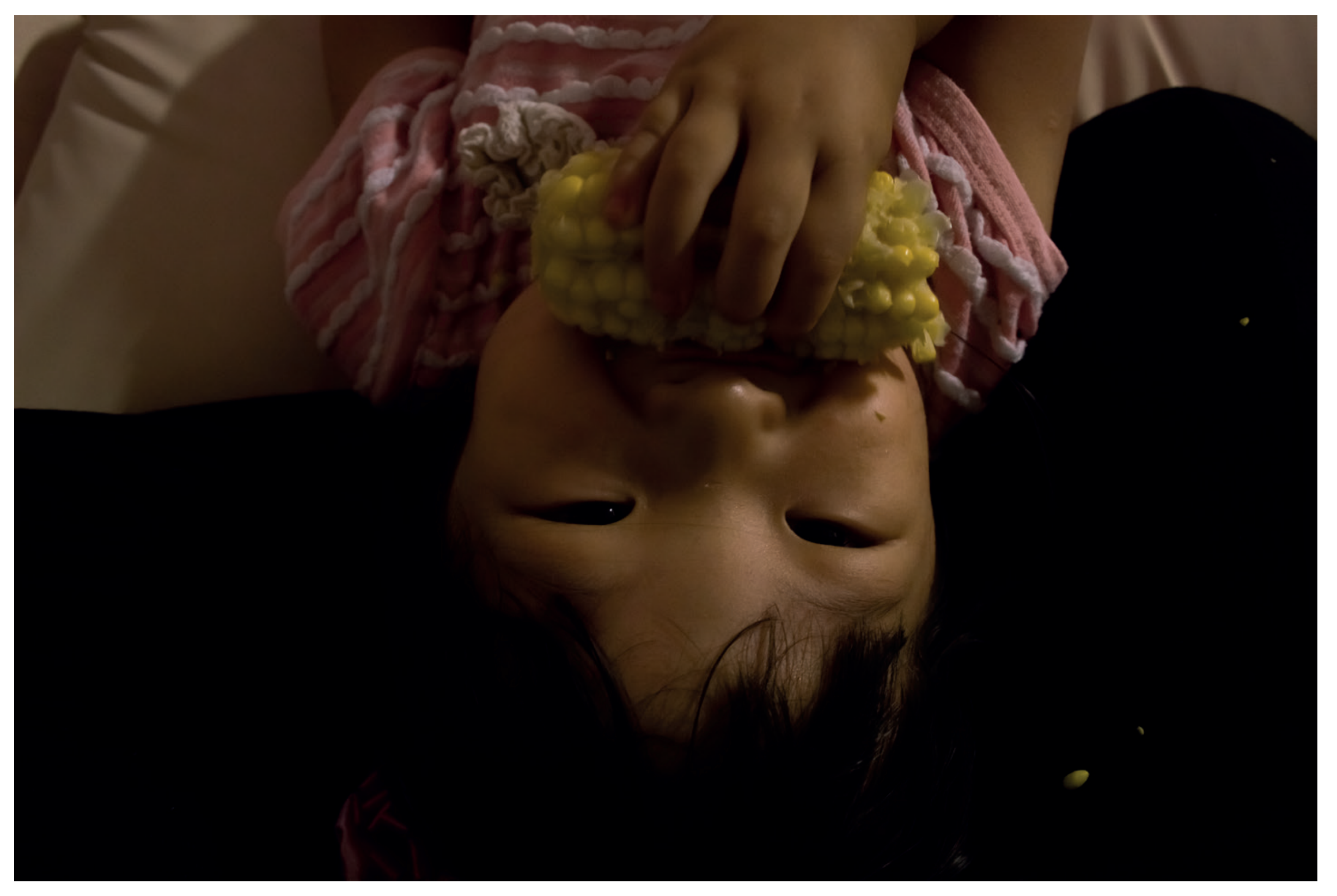




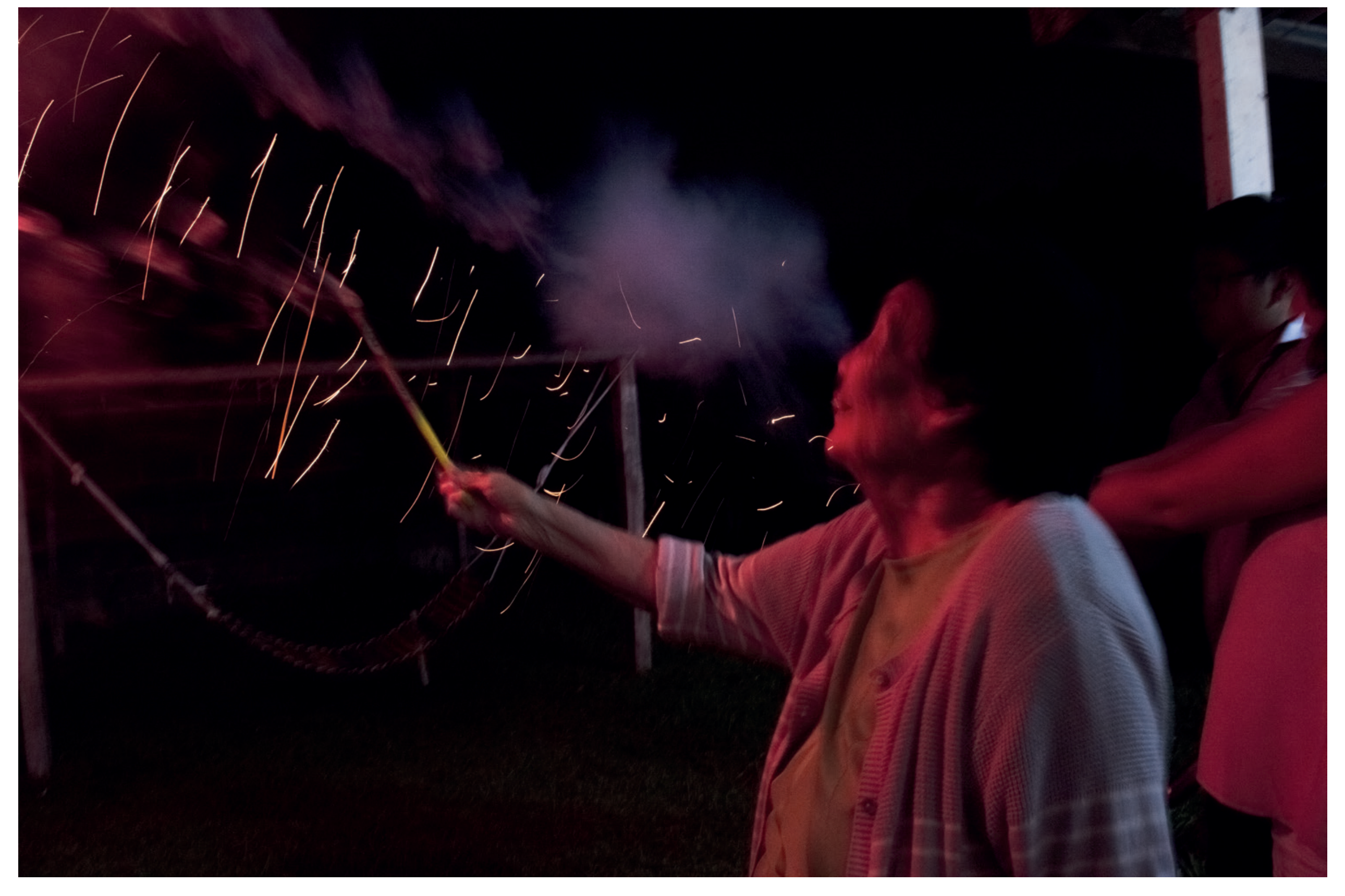


Oinício

Um nó dentro do nó

A beleza de uma árvore não dá para explicar

O melhor são as melancias no verão

Do que são feitos os sonhos?

\section{Quem veio antes}

$$
\text { Meu espelho }
$$

O primeiro cachorro

\section{Um passeio na casa \\ que não tem mais}

Ela costura como se a máquina

fosse extensão de seu corpo

$$
\begin{aligned}
& \text { Os peixes são meio laranja, } \\
& \text { meio água, meio alga }
\end{aligned}
$$

Montanhas são sagradas

Você vai ser sempre uma estrela
Nos despedimos lentamente

de nossas próprias lembranças

$$
\text { Companheiras }
$$

As rosas do meu avô

Dobrar as mangas

Tempo verde musgo

A lua na casca das árvores

Trocamos os pinheiros por ipês

Que saudades, vó

Nossos brinquedos favoritos

Admirável malabares

Ah! Mas temos pinheiros aqui também

Kimonos e havaianas

Milho verde é muito bom

Olha, que bonito!

Como brilham no escuro 


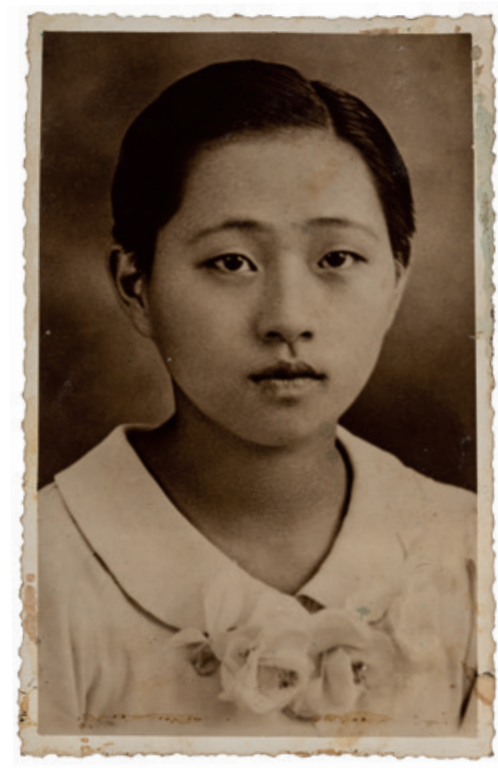

W eu documento de identidade registra dois nomes, não 1 dois sobrenomes, e nem um nome composto. Dois nomes mesmo. O primeiro é brasileiro, Gabriela, e o segundo, japonês, Lissa. Sou brasileira nascida e criada, mas também tenho um nome e um sobrenome que remetem à origem da minha família, uma história que começou muito antes de mim.

$\mathrm{Na}$ família, encontro evidências de minhas origens genéticas, referências culturais, meu berço afetivo. Enquanto o cotidiano atropela, tento, atrapalhada, organizar histórias, documentos, imagens e memórias que por aí ficaram espalhadas. Posuir um arquivo familiar é um privilégio, mas acho que todo mundo tem aquela "caixa de sapato" com o que há de mais precioso, um tesouro particular: cartas, objetos, fotografias, presentes. Minha avó tinha muitos álbuns de família, alguns mais antigos - acho que eram de sua mãe - e outros que ela montou ao longo da vida.

Esses livros de foto sempre exerceram fascínio sobre mim. Desde criança, gosto de sentir o objeto em minhas mãos: a capa dura, as folhas grossas, fotografias em preto e branco, cantoneiras de papel, anotações escritas à mão e aquelas folhas de seda texturizadas que separavam as fotos entre uma página e outra. Passeio os olhos pelos rostos, pelas paisagens e me pergunto: Quem são? Que montanha é essa? Qual foi o destino dos imigrantes desse navio? As fotos são pistas, enigmas, e minha cabeça é povoada por fantasias sobre essas imagens. 
Álbuns são construções intrinsecamente pessoais. Seria possível descobrir as intenções de quem os construiu? Composições pensadas por temas, cronologia, afetos. Existe um mistério que paira sobre esses objetos que vai permanecer sempre velado.

Um passeio pelas imagens pode causar reações particulares de acordo com cada foto ao se identificar rostos de pessoas queridas e lugares especiais. Pode ser que a fotografia traga a alegria de uma lembrança boa ou dor pela saudade das pessoas que não estão mais aqui. As fotos resgatam sempre o mesmo momento em que foram clicadas, mas cada vez que são visitadas, ressoam de maneira diferente no espectador.

Olhando os álbuns, parece que as histórias de família se misturam com minhas memórias pessoais: o primeiro cachorro (meu ou da minha avó?), o som da máquina de costura, os fogos de artifício, as paisagens, viagens, encontros. Cada um que olhar essas fotos, no entanto, vai relacioná-las com algo que lhe tocou, um tipo de empatia entre recordações. As memórias não são só uma espécie de registro do que vivemos, mas também conhecimento, relacionam-se com o aprendizado do sentir. A partir de nossas recordações, acessamos experiências e daí traçamos nossos valores, estabelecemos a maneira como nos colocamos no mundo e nos relacionamos com o outro.

$\mathrm{O}$ que faz uma experiência ser relevante a ponto de se perpetuar na memória? Que lembranças acessamos e quais ficam escondidas em algum canto à espera do gatilho que as dispare? Quando a mente perde essas referências, uma parte de nós também se perde. Ao mesmo tempo, acredito que o que já foi vivido permanece vivo ressoando no tempo, nas pessoas, nas coisas, nada se perde.

Somam-se ao arquivo familiar fotografias que eu mesma tirei, minha própria contribuição para o acervo. Tempos distintos convivem também em relação às técnicas fotográficas: fotos $\mathrm{PB}$ em gelatina de prata, imagens coloridas de filmes ou digitais. Formatos de imagens e câmeras diferentes, imagens amadoras e as feitas em estúdio.

Nas fotos, a beleza da juventude imortalizada: a pele indefectível, o perfil elegante. Pessoas que só vi assim, em fotos, porque as conheci muito tempo depois. Acho sempre estranho imaginar que meus pais já foram crianças. O passar do tempo parece muito óbvio, mas come miudinho; distraídos, nem reparamos nele passando. Tomamos um susto ao perceber que também estamos envelhecendo.

Tem uma foto que fiz da minha avó enquanto ela olhava para essas fotos de família. O dia era de arrumação, antes dela se despedir de sua casa. Não sei se ela ainda era capaz de se lembrar daqueles momentos registrados nas imagens, mas ela olhava as fotografias com a solenidade de quem manipula documentos importantes.

Olho então para meu próprio álbum: minha avó rindo e seu pirulito, fogos de artifício, a batian jogando malabares, o café coando em cima da pia, a fumaça subindo, a garrafa térmica japonesa com tema floral, um sonho, cinco marias no ar recordações e o pé de jasmim-manga, ela dobrando as mangas, quimonos, sapatos de gente grande, calçados de gente pequena...

Quando tudo começa de novo, e viramos crianças. 
As fotografias deste ensaio fazem parte do arquivo da família Oyafuso e do meu acervo pessoal.

As imagens de minha autoria foram realizadas com câmeras analógicas e digitais entre 2010 e 2017. As fotografias foram feitas em São Paulo, Torres del Paine e Arujá. 
Formato: $160 \times 210 \mathrm{~mm}$

Tipologia: Nocturne Serif e Cardo

Miolo: Pólen bold $90 \mathrm{~g} / \mathrm{m}^{2}$

Capa: Markatto Concetto Avorio $250 \mathrm{~g} / \mathrm{m}^{2}$

Impressão: Impressão digital HP Indigo

Projeto gráfico: Gabriela Lissa Sakajiri

Capa: Gabriela Lissa Sakajiri

Preparação: Helena Küller e Tarcila Lucena

Revisão: Marcelo Carpinetti

Impresso em setembro de 2020

pela gráfica Forma Certa - São Paulo 
são paulo

2020 